PNWD-1980-12 HEDR

UC.000

\title{
HANFORD ENVIRONMENTAL DOSE RECONSTRUCTION PROJECT
}

Quarterly Report

June-August 1993

Prepared for the Technical Steering Panel

and the Centers for Disease Control and Prevention

under Contract 200-92-0503(CDC)/18620(BNW)

Battelle

Pacliflc Northwest Laboratories

Richland, Washington 99352

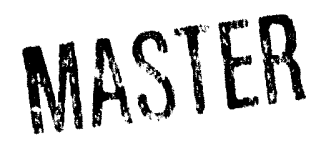

DISTPIBUTION OF THIS DOCUMENT IS UNLIMITED 
PNWD-1980-12 HEDR

UC. 000

\section{HANFORD ENVIRONMENTAL DOSE RECONSTRUCTION PROJECT}

\section{Quarterly Report}

June-August 1993

Compiled By:

Approved By:

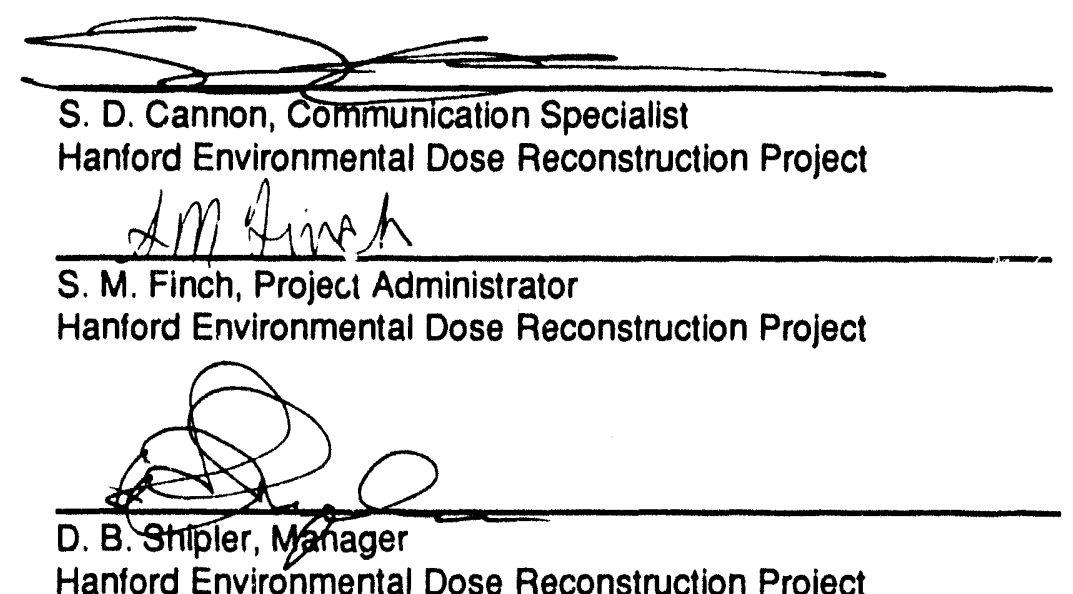

Hanford Environmental Dose Reconstruction Project 


\section{Preface}

This quarterly report summarizes the technical progress and project status for the Hanford Environmental Dose Reconstruction (HEDR) Project being conducted by Battelle. Pacinc Northwest Laboratories (BNW) under contract with the Centers for Disease Control and Prevention (CDC). The Technical Steering Panel (TSF), which is composed of experts in numerous technical fields related to the project, provides technical direction of the project.

Figure 1 shows the Battelle organizational structure of the HEDR Project. Table 1 shows the status of Battelle work to comply with directives issued by the TSP.

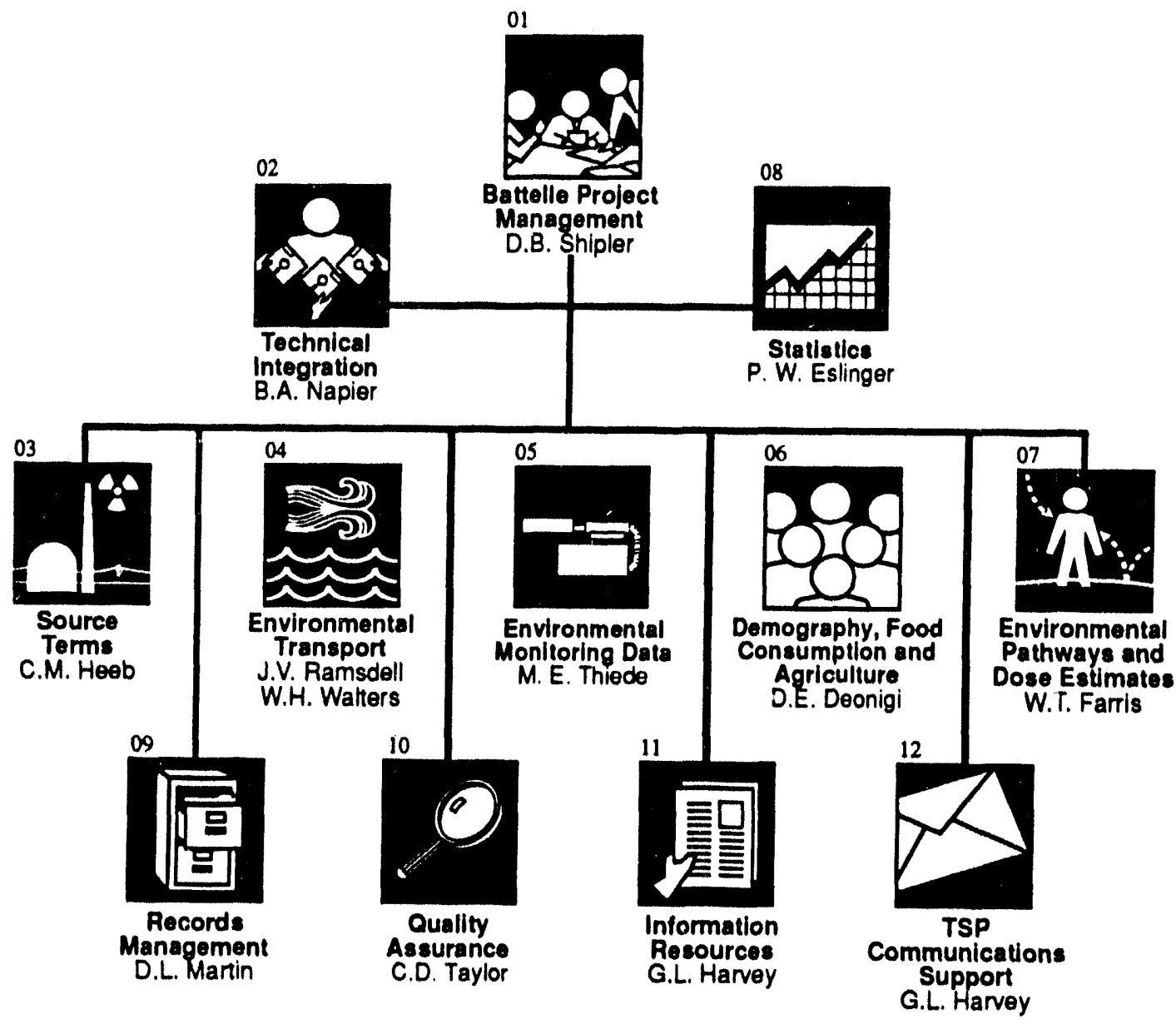

R9205064.3

Figure 1. Organizational Structure of the HEDR Project 
Table 1. Status of Directives ${ }^{(a)}$

\section{Complete}

\begin{tabular}{|c|c|c|}
\hline 88-1-a & Classined Documents & $\mathbf{x}$ \\
\hline $88-1-b$ & Proposals & $\mathbf{x}$ \\
\hline $88-2$ & Vegetation & $\mathbf{x}$ \\
\hline $88-3$ & Status Reports & $\mathbf{x}$ \\
\hline $88-4$ & Ground Water & $\mathbf{x}$ \\
\hline $88-5$ & Maps & $\mathbf{x}$ \\
\hline $88-6$ & Resumes & $\mathbf{x}$ \\
\hline $88-7$ & TSP Comments on Proposals & $\mathbf{x}$ \\
\hline 89-1 & Indian Tribes & $\mathbf{x}$ (work now directed by TSP) \\
\hline $89-2$ & Bloassay Data & $\mathbf{x}$ \\
\hline $89-3$ & Document Handling & $\mathbf{x}$ \\
\hline $89-4$ & Reactor Purging & $\mathbf{x}$ \\
\hline $89-5$ & Modeling Approach & $\mathbf{x}$ \\
\hline $89-6$ & Meeting Materials & $\mathbf{x}$ \\
\hline 89-7 & Technical Communication & $x$ \\
\hline 89.8 & Phase II Planning & \\
\hline
\end{tabular}

89-9 Project QA Plan $\quad x$

89-10 Contracts with Tribes $x$

90-1 Project Direction (Task Plans) $\quad x$

90-2 Dose Cut-Off Limit $\quad x$

92-1 Demography, Food, and Agriculture Tasks $\quad \mathbf{x}$

92-2 Dose Code Development $\mathbf{x}$

93-1 Sensitivity and Uncertainty
Analyses

Milk Production and
Distribution

(a) Note: For simplicity, TSP directives are identifled here using only key words. The complete directives are avallable from the TSP. 


\section{Executive Summary}

The objective of the Hanford Environmental Dose Reconstruction (HEDR) Project is to estimate the radiation doses that individuals and populations could have recelved from nuclear operations at Hanford since 1944. The project is being managed and conducted by Battelle, Pacific Northwest Laboratories (BNW) under contract with the Centers for

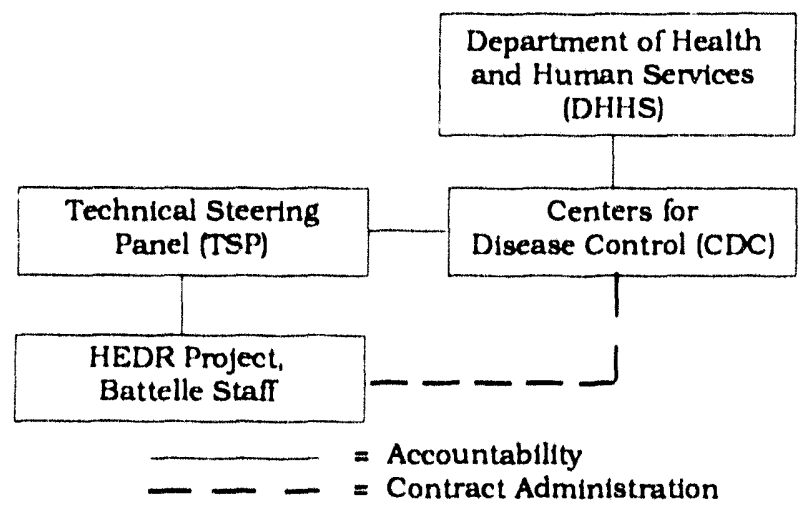

Disease Control and Prevention (CDC). The Independent Technical Steering Panel (TSP) provides technical direction.

The TSP consists of experts in environmental pathways, epldemlology, surface-water transport. ground-water transport, statistics, demography. agriculture, meteorology, nuclear engineering, radiation dosimetry, and cultural anthropology. Included are appointed members representing the states of Oregon. Washington, and Idaho, a representative of Native American tribes, and an Individual representing the public.

The project is divided into the following technical tasks. These tasks correspond to the path radionuclides followed from release to impact on humans (dose estimates):

- Source Terms

- Environmental Transport

- Environmental Monitoring Data
- Demography, Food Consumption, and Agriculture

- Environmental Pathways and Dose Estimates.

The Source Terms Task develops estimates of radioactive emissions from Hanford facllities since 1944. These estimates are based on historical measurements and production information.

The Environmental Transport Task reconstructs the movement of radioactive materials from the areas of release to populations. Movement via the atmosphere, surface water (Columbia River), and ground water is studied.

The Environmental Monitoring Data Task assembles, evaluates, and reports historical environmental monitoring data.

The Demography, Food Consumption, and Agriculture Task develops the data needed to identify the populations that could have been affected by the releases. Population and demographlc information are developed for the general population within the study area. This information is also expected to be developed for several special population groups, Including Native American tribes in the study area.

In addition to population and demographic data. the food and water sources and consumption pat terns for populations are estimated because they provide a primary pathway for the intake of radionuclides. Historical dairy farming practices and milk distribution systems are studied because milk is a significant pathway for lodine-131 to enter the human body. Cows could have eaten vegetation contaminated with this radionuclide.

Lifestyle and food habit information will be developed by the Fred Hutchinson Cancer Research Center (FHCRC) for use in the Hanford Thyrold Disease Study (HTDS).

The Environmental Pathways and Dose Estimates Task uses the Information produced by the other tasks and organizations to estimate the radiation doses individuals could have recelved from Hanford radiation.

Project reports and Hanford-origlnated references used in the reports are made avallable to the publlc in a public reading room. Project progress is documented in this quarterly report, which is avallable to the public. 


\section{Project Summary}

\section{Progress}

Fgure A. 1 in Appendix A shows the status of HEDR Project milestone activities. The following is a summary of activities conducted by HEDR staff from June through August 1993:

- participated in the CDC review of the status of models, computer codes, and other calculational tools to be used for air and rtver pathway dose calculations. The CDC members involved were pleased with the calculational tool set, computer testing, and data fle development (Task 01).

- Initiated a new milestone, HEDR Moriel ValidatIon Results, at the request of the TSP. The results of the validation tests will be reported in this document rather than in the Milestone 0803B model reliability report as originally planned (Milestone 0204C).

- attended the validation of model predictions program (VAMP) meeting at the International Atomic Energy Agency to present an overview of the HEDR Project, focusing on the model validation activities (Subtask 0204)

- published the HEDR Model Validation Plan. PNWD-2 156 HEDR (Milestone 0205E)

- completed final internal development reviews for the AGGREGATE, SHUFFL, DESCARTES, and CIDER components of the environmental accumulation and dose codes for the alr pathway. The air dose code was found to be sound. These reviews mark the omcial transition from development into conflguration management for these components (Subtask 0205).

- completed production runs of hourly lodine-131 air releases from chemical separations plants $T$ and $B$ for the period 1944-1949 (Subtask 0303)

- completed monthly air release estimates for seven radionuclides for $T, B, R E D O X$, and PUREX chemical separations plants from 1944 . 1972 (Subtask 0303)

- completed production runs of the source term river release model (Subtask 0304)

- published the report. A Revlew of Wind Fleld Models for Atmospheric Transport, PNWD-2148 HEDR (Mulestone 0402A)

- completed formal testing of all RATCHET program elements and participated in an independent review of RATCHET curle tests (Subtask 0402)
- completed the software test plan for the Columbla Rlver model and the callbration and validation of the model for unsteady flow hydraulics (flood hydrograph) conditions (Subtask 0404)

- approved the assignment of $M$. E. Thlede as Environmental Monitoring Data Task Leader. He replaced D. H. Denham, whose work as task leader and author of the recent environmental monitoring data reports is greatly appreciated (Task 05)

- published the report. Phase I Summarles of Radionuclide Concentration Data for Vegetation. River Water, Drinking Water, and Flsh, PNWD2145 HEDR (Milestone 0501A)

- Incorporated the TSP comments and published the final version of Estimation of 1945 to 1957 Food Consumption. PNWD-21 13 HEDR (Milestone 0602C)

- completed face finding on the dairy Industry in Whitman. Spokane, and Lincoln counties. The interviews were held to elicit information on commercial milk production and distribution (Subtask 0603).

- completed the Columbla Rlver dosimetry (CRD) code development activities (Subtask 0702)

- recelved comments from the TSP on the previously issued parameter report. In addition. TSP members. G. S. Rocssler and B. Shlelen, met with HEDR staff and interested members of the public during the week of August 9 to review the lodine-131 ingestion dose factor as documented In the parameter report. The lodine-131 ingestion dose factor was found to contribute most to the uncertainty in air pathway doses. The review was positive, and the TSP members did not recommend changing the dose factor as documented (Mllestone 0703B/C).

- prepared preliminary alr pathway dose estimates for the Umatilla, Spokane, Colville, and Kalispel tribes (Subtask 0705)

- approved the assignment of P. W. Eslinger as Statustles Task Leader. He replaced R. O. Gllbert, whose work as task leader and whose statistical support is greatly appreclated. R. O. Gilbert will continue to review project documents and be avallable for consultation. In addition,

J. C. Simpson. Arialysis of Model Reliabllity Subtask Leader, will be leaving BNW effective October 12, 1993, but will complete her HEDR Project work with BNW on a subcontract. Her 
work in developing PILOT and the sensitivity/ uncertalnty plan is also greatly appreclated (Task 08).

- terminated development of the PILOT code because its purpose is completed. The code is not a contract deltverable (Subtask 0803).

- revised the records inventory and disposition schedule (RIDS) to Include configuration management records and fle category changes Identufied during task file reviews. The configuration management category will have all the HEDR Project calculational tools. This "tool box" will form the basis of the technical turnover package to $\mathrm{CDC}$ (Task 09).

- trained the HEDR Project staff who are responsible for conflguration management on the HEDR Conflguration Management Plan (Task $1 \mathrm{C}$

- declassifled 116 Hanford-Site-originated documents, one of which was of potential interest/ use to the HEDR Project (Subtask 1102)

- published the letter report. Fuel-Element Fallures in Hanford Single-Pass Reactors 1944-1971. PNWD-2161 HEDR (Subtask 1103)

- drafted improved procedural guldelines, in support of the U.S. Department of Energy (DOE), which permit TSP members better access to documents of interest or potential use to the HEDR Project (Task 12)

\section{Major Problem Areas or Changes and Action Taken}

Because the fiscal year (FY) 1993 revised scope is challenging some subtask budgets. HEDR Project work will be reprioritized. Effective September 1. 1993, planned work on dose-code development. testing, and validation as well as millk model development activities will be reviewed weekly and controlled to contain costs. The tasks/subtasks affected are Technical Integration. Atmospheric Model, Mulk Model, Environmental Pathways and Dose Estimates, and Analysis of Model Reliability.

The discussion of sensitivity/uncertainty of the dose calculations, originally planned to appear in the model reliability report (Milestone 0803B), will be incorporated Instead into the respective river and alr dose reports (Milestones 0705B and 0705C). In agreement with the TSP and CDC, the publicatJon dates for these Milestone 0705B and 0705C reports have both been rescheduled to February 1994. This timing allows the TSP more opportunity to review the validation test results prior to releasing final dose estimates to the public. These dose estumates will be provided to the TSP for comment in conjunction with the TSP meeting presently scheduled for March 1994. Depending on the extent of the comments, a delay in that meeting could delay the final publication of these dose reports.

\section{Planned Work for the Next Three Months}

- contain HEDR Project costs whlle continuing to meet the scope of work in the contract with CDC (Task 01)

- publish revised integrated task plans (Milestone 0101G)

- write model validation report (Milestone 0204C)

- write key radionuclides released to air, 19441991, report (Milestone 0303D)

- write key reactor releases to the Columbla Rlver. 1944-1991, report (Milestone 0304B)

- rUn RATCHET for HTDS dose calculations (Subtask 0402)

- complete technical work and turn over com. puted water concentrations to the Environmental Pathways and Dose Estimates Task (Subtask 0404)

- publish the letter report: atmospheric model database status (Milestone 0405B)

- publish the vegetation monitoring data report for 1948-1951 and the blas and data correction report for the same period (Milestone 0502B)

- publish the vegetation monitoring data summaries for 1952-1983 (Subtask 0502)

- write the milk production/distribution report (Milestone 0603D)

- review and evaluate the preliminary data sub. mitted to BNW by Native American tribes (Subtask 0605)

- update the parameters report (Milestone 0703C)

\section{Budget Status}

Figure 2 shows the budget status of the HEDR Project. Table A.1 In Appendix A shows FY 1993 costs and budget by task and subtasks. Figure A.2 shows TSP budget status. Figure A.3 shows Native American research budget status.

\section{Capltal Status}

Nothing new to report. 


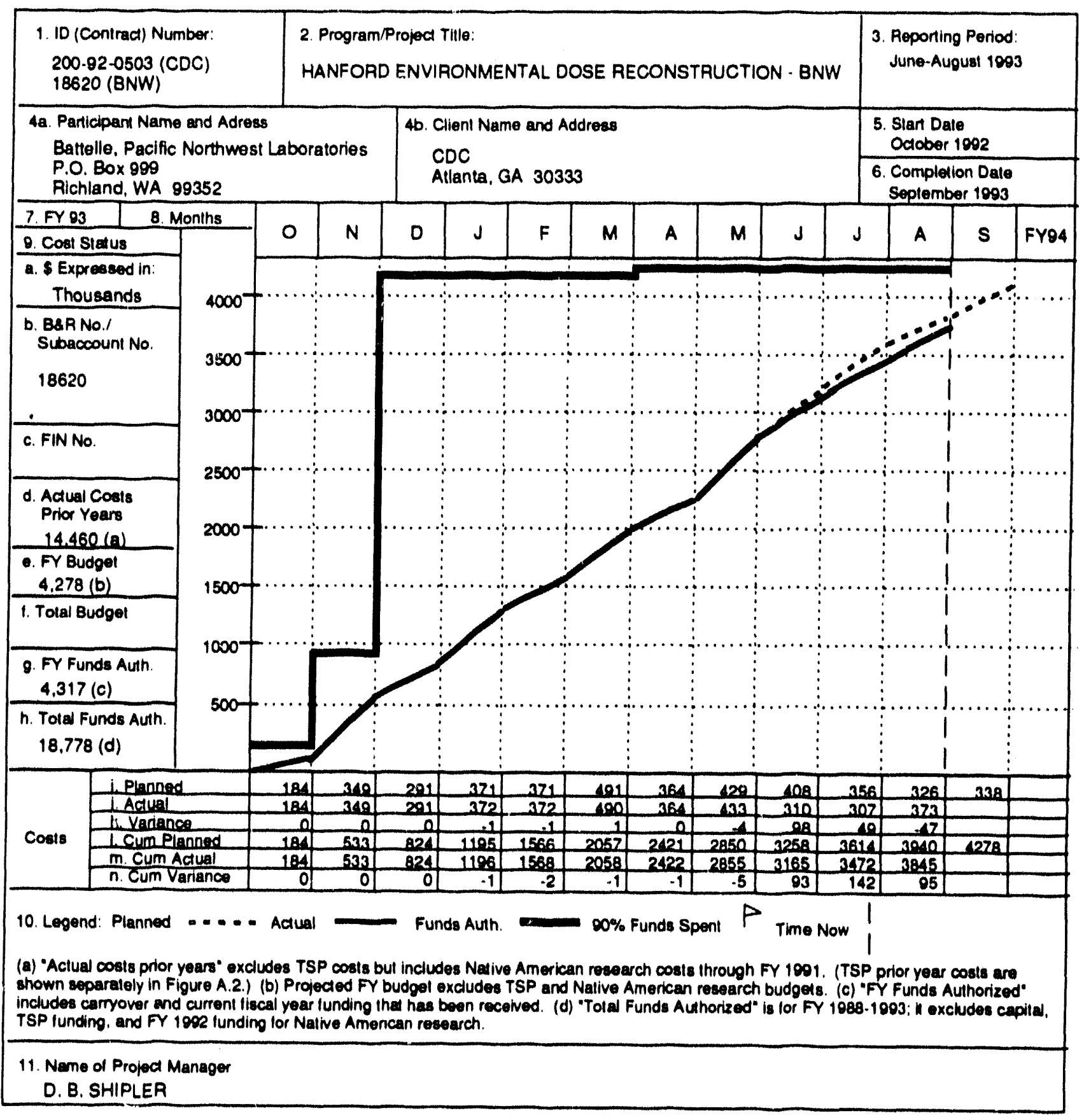

Figure 2. HEDR Project Budget Status - Battelle Pacific Northwest Laboratories 


\section{Acronyms and Abbreviations}

\begin{tabular}{|c|c|c|c|}
\hline AGGREGATE & component of DESCARTES & NFCS & National Food Consumption Survey \\
\hline $\mathbf{A P}$ & Assoclated Press & NPT & Nez Perce Tribe \\
\hline BNW & $\begin{array}{l}\text { Battelle Pacinc Northwest } \\
\text { Laboratories }\end{array}$ & NT1S & $\begin{array}{l}\text { National Technical Information } \\
\text { Service }\end{array}$ \\
\hline CAT & Coeur d'Alene Tribe & OMB & Omce of Management and Budget \\
\hline $\mathrm{CDC}$ & $\begin{array}{l}\text { Centers for Cisease Control and } \\
\text { Prevention }\end{array}$ & PILOT & $\begin{array}{l}\text { please iterate lots of times } \\
\text { (computer code) }\end{array}$ \\
\hline CIDER & $\begin{array}{l}\text { calculation of individual doses from } \\
\text { environmental radionuclides } \\
\text { (computer code) }\end{array}$ & PNL & $\begin{array}{l}\text { Pacinc Northwest Laboratory } \\
\text { (operated for DOE by Battelle } \\
\text { Memorlal Instltute) }\end{array}$ \\
\hline $\mathrm{CRD}$ & $\begin{array}{l}\text { Columbla River dosimetry (computer } \\
\text { code) }\end{array}$ & $\begin{array}{l}\text { QA } \\
\text { RATCHET }\end{array}$ & $\begin{array}{l}\text { quallty assurance } \\
\text { regional atmosphertc transp }\end{array}$ \\
\hline $\begin{array}{l}\text { CT } \\
\text { CTUIR }\end{array}$ & $\begin{array}{l}\text { Colville Tribe } \\
\text { Confederatea Tribes of the Umatlla }\end{array}$ & & $\begin{array}{l}\text { for Hanford emissions tracking } \\
\text { (computer code) }\end{array}$ \\
\hline CIVIT & Indian Reservation & RECIPE & component of DESCARTES \\
\hline DESCARTES & $\begin{array}{l}\text { dynamic estimates of concentrations } \\
\text { and accumulated radionuclides in }\end{array}$ & REDOX & $\begin{array}{l}\text { reduction and oxydation } \\
\text { (separations process) }\end{array}$ \\
\hline & code) & RFP & request for proposal \\
\hline DOE & U.S. Department of Energy & RIDS & $\begin{array}{l}\text { records Inventory and disposition } \\
\text { schedule }\end{array}$ \\
\hline DOE.HQ & $\begin{array}{l}\text { U.S. Department of Energy } \\
\text { Headquarters }\end{array}$ & RL & $\begin{array}{l}\text { U.S. Department of Energy Richland } \\
\text { Operations }\end{array}$ \\
\hline DOI & "do" lodine (computer code) & $R M$ & reactor model (computer code) \\
\hline DQO & Data Quality Objective & SESRC & Social and Economic Sciences \\
\hline FHCRC & $\begin{array}{l}\text { Fred Hutchinson Cancer Research } \\
\text { Center }\end{array}$ & & $\begin{array}{l}\text { Research Center (Washington State } \\
\text { University) }\end{array}$ \\
\hline FY & nscal year & SHUFFL & component of DESCARTES \\
\hline GENII-S & generation II-SUNS (computer code) & sow & statement of work \\
\hline HEDR & $\begin{array}{l}\text { Hanford Environmental Dose } \\
\text { Reconstruction }\end{array}$ & $\begin{array}{l}\text { ST } \\
\text { STRM }\end{array}$ & $\begin{array}{l}\text { Spokane Tribe } \\
\text { source term release model }\end{array}$ \\
\hline HEDRIC & $\begin{array}{l}\text { Hanford Environmental Dose } \\
\text { Reconstruction Integrated } \mathrm{Co}\end{array}$ & & (computer code \\
\hline HHIN & Hanford Health Information Network & STRRM & $\begin{array}{l}\text { soiurce term river release model } \\
\text { (computer code) }\end{array}$ \\
\hline HNIS & $\begin{array}{l}\text { Health and Nutrition Information } \\
\text { Service }\end{array}$ & $\begin{array}{l}\text { SUNS } \\
\text { TSP }\end{array}$ & $\begin{array}{l}\text { sensltivity/uncertainty system } \\
\text { Technical Steering Panel }\end{array}$ \\
\hline HTDS & Hanford Thyrold Disease Study & USDA & U.S. Department of Agriculture \\
\hline IAEA & International Atomic Energy Agency & UT & Umatllla Tribe \\
\hline $\begin{array}{l}\text { IHS } \\
\text { KT }\end{array}$ & $\begin{array}{l}\text { Indian Health Service } \\
\text { Kalispel Tribe }\end{array}$ & VAMP & $\begin{array}{l}\text { validation of model predictions } \\
\text { program }\end{array}$ \\
\hline NAS & National Academy of Sciences & WST & Warm Springs Tribe \\
\hline NAWG & $\begin{array}{l}\text { TSP Native American Working } \\
\text { Group }\end{array}$ & $\begin{array}{l}\text { WSU } \\
\text { YIN }\end{array}$ & $\begin{array}{l}\text { Washington State University } \\
\text { Yakıma Indian Nation }\end{array}$ \\
\hline
\end{tabular}




\section{Contents}

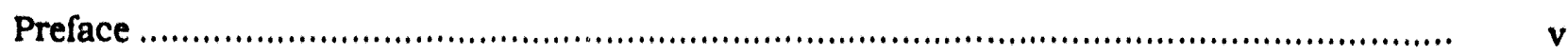

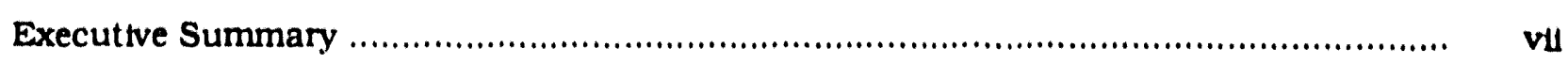

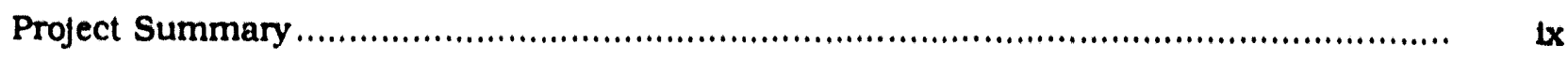

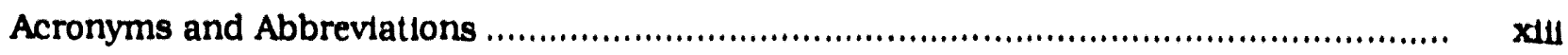

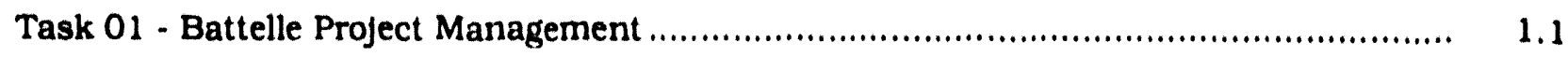

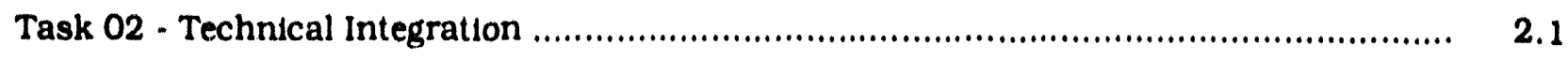

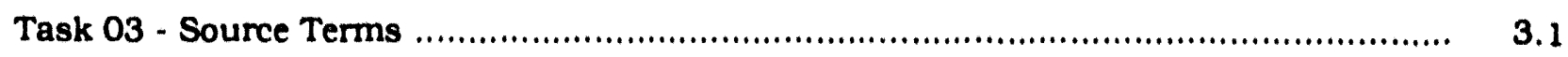

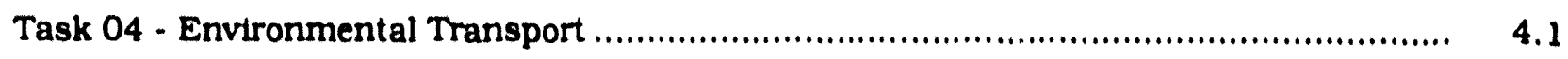

Task 05 - Environmental Monitoring Data ................................................. 5.1

Task 06 - Demography, Food Consumption, and Agriculture ................................. 6.1

Task 07 - Envtronmental Pathways and Dose Estımates ...................................... 7.1

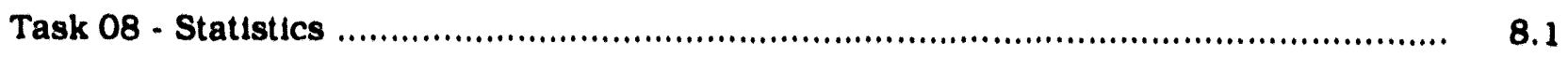

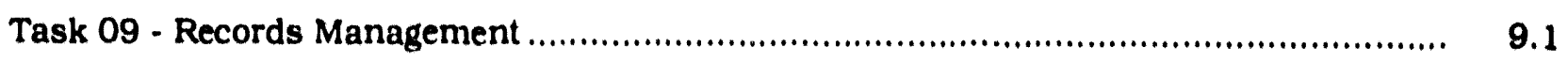

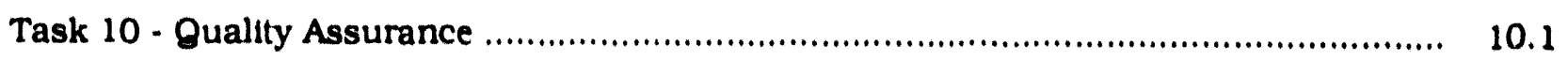

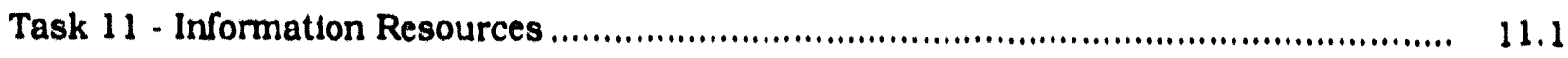

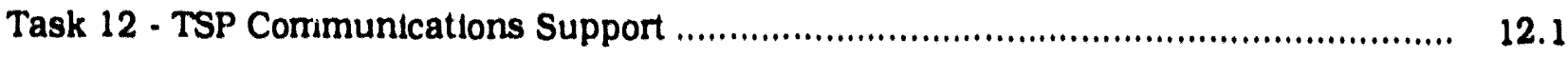

Appendix A - Mulestones, Schedule, and Costs .................................................... A.

Appendix B - Hanford-Site-Originated Documents of Potentlal Interest/Use to the HEDR Project - Placed in the RL Public Reading Room During June-August 1993

Appendix C - HEDR Documents to the TSP - June-August 1993 _............................. C.1

Appendix D - HEDR Presentation Handouts to the TSP - June-August 1993 ................ D.1

Appendix E - HEDR Open-Literature Publications and Presentations June-August 1993

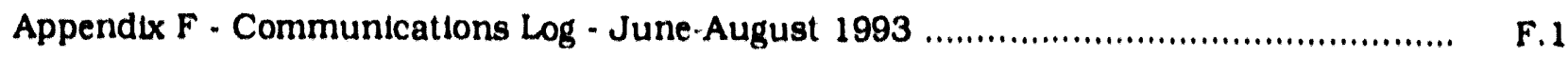




\section{Figures}

1 Organizational Structure of the HEDR Project ....................................... v

2 HEDR Project Budget Status - Battelle Pacific Northwest Laboratories ................. xd

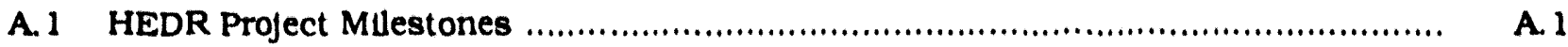

A.2 Technical Steerng Panel Budget Status .................................................. A.

A.3 Native American Research Budget Status ............................................ A. 12

\section{Tables}

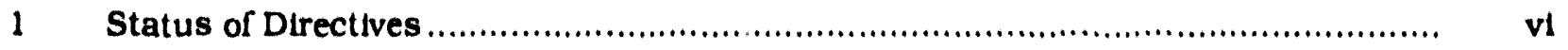

11.1 Declassification of Hanford-Site-Originated Documents .............................. 11.2

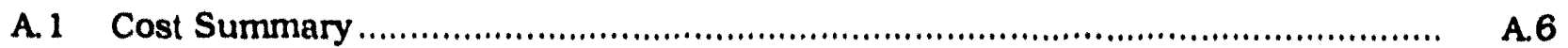




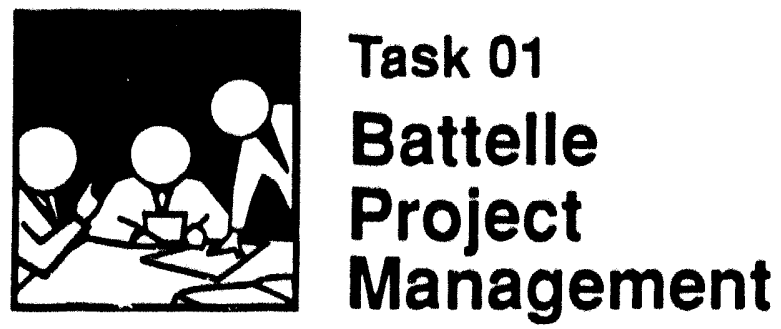

\section{Objective}

The objective of the Battelle Project Management Task is to provide project planning, control, and management of Battelle dose reconstruction work in accordance with the Centers for Disease Control (CDC) contract and Technical Steering Panel (TSP) technical direction.

\section{Progress}

\section{Mllestone 0101G - Revised Integrated Task Plans, due Aprll 1993 and rescheduled to September 1993}

- revised each of the task's plans according to the new scope realignment agreed to by the TSP and CDC

\section{Mllestone 0101I - Project Final Report, due Aprll 1994}

- sent a letter to the TSP and CDC defining the content of this report

\section{Other Activities}

- participated in the CDC review of the status of models, computer codes, and other calculational tools to be used for alr and river pathway dose calculations. The CDC members involved were pleased with the calculational tool set, computer testing, and data fle development.

- recelved praise from DOE-Headquarters (HQ) for BNW stafts' involvement in the DOE-HQ Classin. cation Assessment Team review and for the draft document which deflnes document access procedures. This should help TSP members more readlly gain access to documents pertinent to the HEDR Project.

- requested an administrative extension to the CDC contract for processing and shipping records after May 31, 1994. No budget Increase is required.

- Issued Document Preparation Plan internally to HEDR Stafl. This plan streamlines the HEDR document prepasation and review process.
- Interviewed by Cable News Network (CNN) on the purpose and scope of the HEDR Project study

\section{Major Problem Areas or Changes and Action Taken}

Because FY 1993 scope is challenging some subtask budgets, HEDR Project work will be reprioriUzed. Ellective September 1, 1993, planned work on dose-code development, testing, and validation as well as milk model development activities will be reviewed weekly and controlled to contain costs. The tasks/subtasks affected are Technical IntegratIon. Atmospheric Model. Milk Model, Envtronmental Pathways and Dose Estimates, and Analysis of Model Reliability.

Eltectuve August 9, S. D. Cannon, who has been the HEDR Communication Specialist, is the new Publlcatlons Manager. J. A. Shaw, the former Publications Manager, resigned from BNW. Her work in developing the HEDR document publication plan is greatly appreclated.

\section{Variance}

No signifleant cumulative variance.

\section{Planned Work for the Next Three Months}

- contain HEDR Project costs while continuing to meet the scope of work in the contract with CDC

- publish the revised integrated task plans (Milestone 0101G) 


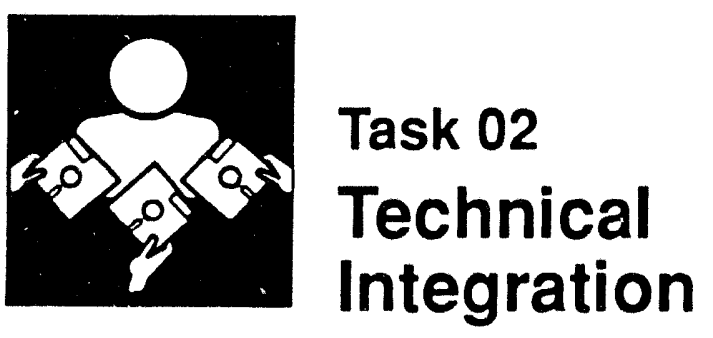

\section{Objective}

The objective of the Technical Integration Task is to provide technical overvlew of the project to ensure that approprlate technical activities are planned, that approprlate information is generated, and that technical task work is integrated effectively for performing the final dose calculations.

\section{Progress}

\section{Milestone 0204C - Letter Report: HEDR Model Validation Results, due December 1993}

- Initiated a new milestone at the behest of the TSP. The results of the validation tests will be reported in this document rather than in the Milestone $0803 \mathrm{~B}$ model reliabillty report as originally planned.

\section{Milestone 0205E - Letter Report: Project Model Valldation Plan, due April 1993, rescheduled to} June 1993 and completed (PNWD-2156 HEDR)

- published the HEDR Model Validation Plan. The plan presents a selection of 14 data sets and the calculations and evaluations required to validate the entire HEDR toolbox. A presentation on the validation plan was also given to the TSP at the meeting in Post Falls, Idaho.

\section{Other Activities}

- Initlated validation efforts. Data sets for all validation tests have been assembled.

- participated in the TSP ad-hoc reviews of the validation plan and proposed dose code parameters. The TSP members involved were pleased with the validation plan and agreed with the pararneter values developed for the computer codes. There was concern that the schedule will not allow enough time for the TSP to decide whether the validation work is sumicient for the project to nroceed with dose calculations. The validation work schedule has, therefore, been accelerated by incorporating sor.te validation runs In the code testing process, and the dose calculation schedule has been slipped. D. S. Barth. TSP, will submit a written report of the conclusions.
- held a management-level conference telephone call between the CDC. FHCRC/HTDS, and BNW. Agreement was reached on transfer of data between the projects. Exchanged test data fles with HTDS three times. Minor incompatibllities were noted, and the nles revised. The process for data interchange has been established and works well.

- held a working-level conference call between the CDC, FHCRC/HTDS, and BNW. Several more technical issues were resolved.

- completed code walk-throughs of the DESCARTES and CIDER computer codes. Minor revisions were required, but the major code structure and implementation were found to be adequate. The detalled walk-throughs on AGGREGATE were completed before June. Those for SHUFFL were completed June 16, those for DESCARTES on June 29, and for CIDER on July 7-8, during the CDC programmers' visit.

- completed final internal development reviews for the AGGREGATE, SHUFFL, DESCARTES, and CIDER components of the environmental accumulation and dose codes for the air pathway. The alr dose code was found to be sound. These reviews mark the oflicial transition from development into configuration management for these components. The reviews consist of review of the module development folders, review of the developer tests for completeness, and review of the design clocumentation and users' manuals for completeness and consistency.

- prepared integration test plans on the basis of lessons learned in the final internal development review process for the Hanford Environmental Dose Reconstruction Integrated Codes (HEDRIC) system up to CIDER, and prioritized the tests. Completed testing of the SHUFFL. DESCARTES. 
and AGGREGATE codes. Initlated testing of the CIDER code. Participated in a review of the code development, test strategy, and test results.

- attended the VAMP meeting at the International Atomic Energy Agency to present an overview of the HEDR Project (focusing on the model val:dation activities) and to present the Hanford Scenario (an accidental release of lodine-131 betng used as a test scenario in VAMP). The Hanford Scenarlo will be used, with initialization, at the Multuple Pathways Working Group meeting the first week of October 1993. The Hanford Scenario will include the resulting data in a separate volume, which must be prepared before the meeting.

- participated in a meeting with TSP members to review parameters for the DESCARTES and CIDER codes in Richland. Washington

- transferred all Technical Integration Task records not in current use to the HEDR Project Omce for processing

\section{Major Problem Areas or Changes and Action Taken}

As anticipated, the testing process has identified some errors in the implementation of the mociels in the computer codes. These continue to be corrected as they are identifled. This requires continual interaction between the coders and the testers. The acceleration of the validation efforts will require some reprioritization of funding. This is anticipated to be done by exchanging FY 1993 dose calculation funds with FY 1994 validation funds.

\section{Variance}

The cumulative ccst overrun was caused largely as a result of the extended testing of the computer codes, as well as the acceleration of the validation activities. The budget deficit for FY 1993 will balance out in FY 1994.

\section{Planned Work for the Next Three Monitins}

- write model validation report (Mulestone 0204C)

- coordinate activities with FHCRC

- complete testing of environmental accumulation and dose models 


\section{$\left\{\begin{array}{l}\text { Task 03 } \\ \text { Source } \\ \text { Terms }\end{array}\right.$}

\section{Objective}

Source terms are the amount and type of radioactive materials released to the environment. The objective of the Source Terms Task is to develop estimates of radioactive emissions since 1944 from Hanford facilities based on historical measurements and production information. Source term estimates are used by Environmental Transport Task members to reconstruct the concentrations of radionuclides in the environment.

\section{Progress}

\section{Radioactlve Releases to Alr (Subtask 0303)}

- completed production runs of hourly lodine-131 air releases from chemical separations plants $T$ and $B$ for the period 1944-1949. The production runs include running the reactor model (RM). The RM runs provide input flles to the "do" lodine (DOI) (separations plant dissolver operations) and source term release model (STRM) (hourly lodine-131 release calculations) computer codes. The production runs provide the source term input to the atmospheric transport model RATCHET. RATCHET provides estimates of ground deposition of lodine-131 required for lodine-131 dose calculations. Provided 100 Monte Carlo realizations as well as the "best estimate" deterministic case. This fulnils an Internal project milestone which is a prerequisite for completing dose estimates from this source.

- completed monthly air release estimates for seven radionuclides for $T, B, R E D O X$, and PUREX chemical separations plants from 1944 through 1972

\section{Surface Water Releases (Subtask 0304)}

- completed production runs of the source term river release model (STRRM). These runs provide monthly release estimates of twelve radionuclides to the Columbla River throughout the operating history of the eight single-pass Hanford production reactors. The estimates include the contribution to lodine-131 and neptunium-239 from nearly 2000 fuel-element fallures that occurred during the operation of the elght production reactors. Provided 100 Monte Carlo realizations for seven key radionuclides as well as the "best estimate" deterministic case. These fles form the source term input for the river transport model code CHARIMA. The production of these files fulnlls an internal project milestone required to estimate doses from the Columbla River.

\section{Major Problem Areas or Changes and Action Taken}

None.

\section{Varlance}

No significant cumulative vartance.

\section{Planned Work for the Next Three Months}

- write key radionuclides released to alr, 19441991, report (Milestone 0303D)

- write key reactor releases to the Columbia River. 1944-1991, report (Milestone 0304B)

- assemble Information required to complete the Hanford historical releases report (Milestone 0306A) $\square$ 


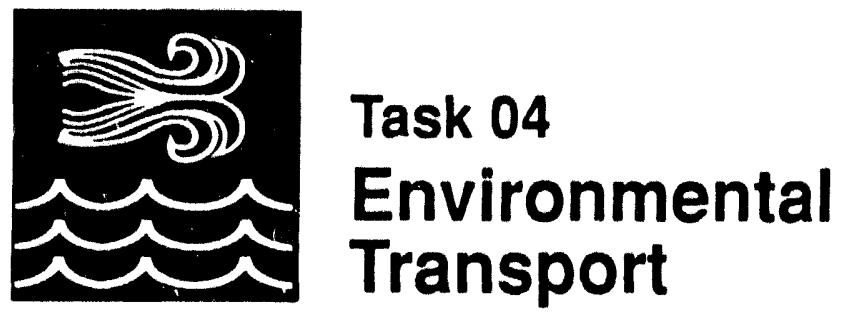

\section{Objective}

The objective of the Environmental Transport Task is to reconstruct the movement of radioactive materlals (the source term information) from the areas of release to the environmen:. Radionuclide movement via the atmosphere, Columbla Rtver, and groundwater is studied.

\section{Progress}

Millestone 0402A - Wind Field Modeling White

Paper, due FY 1991, reschizduled to June 1993 and completed (PNWD-2148 HEDR)

- published the report. A Reulew of Wind Fleld Models for Atmosphertc Transport

\section{Mllestone 0404C + 0404B - Report on Columbla} River Modeling Approach + Letter Report: Columbla River Conceptual Model, due June 1993 and rescheduled to December 1993

- completed the software test plan for the Columbla River model. The channel geometry data nle for the Columbla River from Priest Rapids labove the reactors) to river Mile 100 just below Portland. Oregon was completed and checked for accuracy. Testing of the model under steady now conditions was completed. The tests were conducted for all posslble river development conditions for the 1950-1970 time span which involves the presence and absence of dams and the range of expected river discharges. These tests are used to confirm that the model can handle Columbla River hydraulics and to determine the proper river-channel roughness coemclent.

- completed the calibration and validation of the model for unsteady flow hydraulics (flood hydrograph) conditions

- began to modify the Columbla River model to compute decay for the radionuclides of interest and prepare the source-term input nles for the eight reactor locations

- attended the July TSP meeting at Post Falls, Idaho. A summary of the work completed to that time was presented to the TSP Environmental Transport Subcommittee on July 15.

- completed the data fle for emuent plume corrections

\section{Milestone 0405B - Letter Report: Atmospherlc} Model Database Status, due September 1993

- submitted this report to the HEDR Project Omce for editing

\section{Other Activities}

- completed formal testing of all RATCHET program elements. Revised the RATCHET user's guide.

- participated in an Independent review of RATCHET code tests

- continued studies of sensitivity of monthly output from RATCHET to changes in the code parameters.

- completed meteorological database review. Transferred Anal data to the SUN computer and reran data test and summary programs to confirm successful data transfer. Ran RATCHET with all data through 1948 as final check on the data.

- started model validation runs. Completed 100 realizations of transport and diffusion calculations for the 1949 Green Run. Completed 100 realizations of 1945 and 1946 for comparison of lodine deposition estimates with monitoring data. Began data preparation for modeling the 1983 through 1986 krypton-85 releases.

- particlpated with TSP members and other HEDR staff in a workshop on model validation 


\section{Major Problem Areas or Changes and Action Taken}

There have been a few minor problems with the Columbia Rtver software validation sequence work being conducted under Subtask 0404. The result is a slip of schedule by two weeks. This will not Impact the TSP validation review scheduled for October.

\section{Varlance}

The cumulative cost underrun in Subtask 0404 was caused by involces not yet recelved and efforts to conserve funds for the experimental and produc. tion runs scheduled for September. The current balance of $\$ 90 \mathrm{~K}$ includes a subcontract commitment of $\$ 47 \mathrm{~K}$ to Washington State University (WSU).

\section{Planned Work for the Next Three Months}

- complete atmospheric model validation com. puter runs and analyze the results (Sublask 0402)
- complete documentation of the RATCHET tests (Subtask 0402)

- complete model sensituvity/uncertainty tests (Subtask 0402)

- complete supporting documentation for RATCHET Input data (Sublasi 0402)

- complete documentation of the RATCHET code (Subtask 0402)

- run RATCHET for HTDS dose calculations (Subtask 0402)

- complete technical work and turn over computed water concentrations to the Environmental Pathways and Dose Estimates Task (Subtask 0404)

- draf report on the Columbla RJver modeling approach (Mllestones 0404B+C)

- publish the letter report: Atmospheric Model Database Status (Milestone 0405B) 


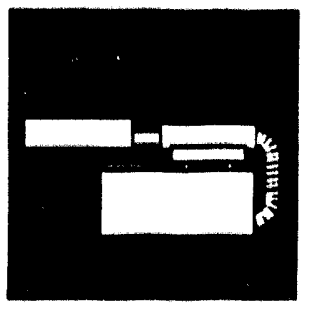

\section{Task 05 \\ Environmental \\ Monitoring Data}

\section{Objectlve}

The objective of the Environmental Monitoring Data Task is to search, retrleve, evaluate, and summartze key historical measurements of the concentrations of radionuclides in the environment around the Hanford site. Radionuclide concentrations have been measured at vartous times in alr, drinking water, foods. nsh. the Columbla River, soll, and in other materlals. These measurements are evaluated to estimate their accuracles and then used by the Environmental Pathways and Dose Estimates Task to estimate radiation doses and by the Environmental Transport Task to calibrate and validate computer models.

\section{Progress}

\section{Milestone 0501A - Environmental Monitoring Data Final Report, due FY 1991, rescheduled to June 1993 and completed (PNWD-2145)}

- published the report, Phase I Summarles of Radionuclide Concentration Data for Vegetation. River Water, Drinking Water, and Fish

Mllestone 0502B - Letter Report: Vegetation Monitoring Data (1948- 1951), Blas and Data Correction, due February 1992 and rescheduled to September 1993

- separated the vegetation monitoring data and the blas and data correction factors into two reports. Both are presently in the c'earance process and will be published in September. The data report will be issued as a background information report with the data itself avallable through the TSP on a diskette.

\section{Mllestone 0502C - Summary Report:}

Environmental Monltoring Data Located to Date, due September 1993 and rescheduled to December 1993

- submitted an outline of this fnal report to the TSP

- reviewed data nles and tables of bloaccumulation factors to ensure that sample sizes are adequate for appropriate statistical comparisons

\section{Surface Water Monltoring Data (Subtask 0504)}

- presented an overview of the Columbla River data at the July TSP meeting In Post Falls, Idaho

\section{Major Problem Areas or Changes and Action Taken}

The two Milestone 0502B reports have been delayed by changes in direction as to whether to publish the reports or place them in the HEDR Project Omce fles to reduce cost. Now that the HEDR Project OMce has decided to publish these reports, they will be completed in September.

M. E. Thlede was assigned Leader of the Environmental Monitoring Data Task, effective June 18. Because M. E. Thiede has been the Deputy Task Leader, performing the bulk of the technical work for over a year, he is in a good posittion to continue the critucal work of preparing data flies and develop. Ing parameter information for dose codes and valldation actvities. Former task leader, D. H. Denham. will support Thiede through the transition period and provide consultation and review through the end of the contract.

The remainder of the Environmental Monltoring Data Task budget is reserved for completion of the Mulestone $0502 \mathrm{C}$ report.

This limited budget has delayed drafting the Mulestone 0502C report. It is now scheduled to be published in December 1993. 


\section{Variance}

No significant cumulative varlance.

\section{Planned Work for the Next Three Months}

- publish the vegetation monltoring data report for 1948-1951 and the blas and data correction report for the same period (Mllestone 0502B)

- publish the vegetation monitoring data summa. ries for 1952-1983 (Sublask 0502)
- prepare the environmental monitoring data summary report (Milestone 0502C)

- continue to evaluate the quality of the data for estimating bloaccumulation factors for nsh in the Columbla River

- continue to supply environmental monitoring data needs to other HEDR tasks as requested 


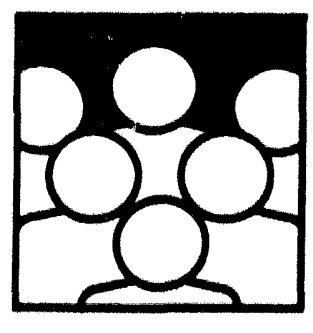

\section{Task 06 Demography, Food Consumption, and Agriculture}

\section{Objective}

The objective of the task is to develop the population and agricultural data needed to estimate the populathon doses that may have resulted from historical releases of radioactlve materlals from operations at the Hanford SIte.

\section{Progress}

\section{Milestone 0602C - Food Consumption Report, Goneral Population, due March 1993 and completed (PNWD-2113 HEDR)}

- Incorporated the TSP comments and published the final version of this report. Estimation of 1945 to 1957 Food Consumption

\section{MIlestone 0603D - Milk Production/Dlatribution} Report, 1944-1891, due March 1993 and rescheduled to December 1993

- completed fact inding on the dairy industry in Whitman, Spokane, and Lincoln countles

- processed the information collected in the taped Interviews for eventual presentation to three experts and ultimately for the TSP to review

- facilitated information collectjon from the three experts for review and analysis

- Incorporated the suggestions of the three experts and D. W. Price of the TSP In the milk study. One of the recommendations involved follow-up Interviews to clartfy Information from Kuttitas. Yakima, and Benton countues.

- completed compllation of the RECIPE nles to be used as input to VESCARTES

\section{Natlve American Data (Subtask 0605)}

- provided work planning guldance to the Warm Springs, Nez Perce, Coeur d'Alene, Spokane, and Yakuma tribes

- met with representatives of the Spokane Tribe to discuss preliminary atr pathway dose estimates
- met with representatives from the Agency for Toxic Substances and Disease Reglstry to brief them on trtbal Involvement in the HEDR Project

- met with TSP, CDC, and Hanford Thyrold Dlsease Study representatlves to update the status of tribal involvement in HEDR and to plan the July meeting of the Native American Workung Oroup (NAWG)

- attended a meeting of the NAWG In Post Falls. Idaho

- revlewed data summarles submitted by the Kallspel. Colville, Coeur d'Alene, and Nez Perce tribes

\section{Major Problem Areas or Changes and Action Taken}

Athough the fnal milk report (Milestone 0603D) will be published later than orfginally planned, the milk distribution data are avallable. The delay in the report will, therefore, not impact the dose calculations.

\section{Varlance}

The cumulative cost undermun was caused by a delay in recelving two involces.

\section{Planned Work for the Next Three Months}

- attend TSP meeting in October on feeding regimes and collect data for the RECIPE component of DESCARTES (Subtask 0603)

- write the milk production/distribution report (Milestone 0603D) 
- plan and partjcipate in the training sessions for the NAWO regarding implementation of data collection protocol (Subtask 0605)

- review and evaluate the preliminary data sub. milted to BNW by Native American tribes

(Subtask 0605)
- provide guldance to Natuve American tribal representatives who plan to come to Seattle. Washington to review unpublished matertals stored at the Sand Polnt Federal Archives facillty (Subtask 0605) 


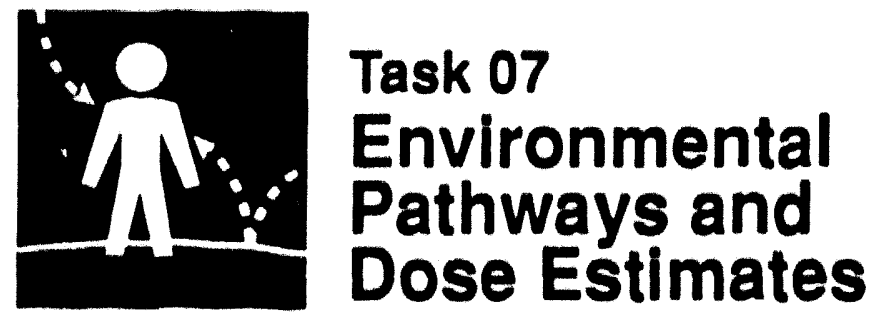

\section{Objective}

The objectlve of the task is to use calculated and measured concentrations of radionuclides provided by members of the Environmental Transport Task and the Environmental Monltoring Data Task to calculate doses to representative individuals, and specinc individuals. These calculations include doses via direct transfer of radionuclides from concentrations in alr and water to people (such as breathing. drinking, and immersion). The calculations also include doses from radionuclide concentrations in air and water trans. ferred through environmental pathways, such as soll, plants, animals, and nsh, to people.

\section{Progress}

\section{MIlestone 0703C - Letter Report: Progressive Revislon of Mllestone 0703B Key Radionucllde Parameters, due December 1993}

- continued work on this milestone. The collectlon of references and Hanford-specinc data for the river environmental accumulation and dose models has been the focus of recent activities. Comments on the previously issued parameter report (Milestone 0703B) were recelved from the TSP. The TSP comments will be addressed in the re-issued parameter report. The parameters will be single deterministic values that will be used to support the river dose calculations. TSP members, C. S. Roessler and B. Shlelen, met with HEDR staff and interested members of the public to review the lodine-131 ingestion dose factor as documented in the parameter report. The lodine-131 ingestion dose factor was found to contribute most to the uncertainty in air pathway doses. The review was posituve, and the TSP members did not recommend changing the dose factor as documented.

\section{Milestone 0705C + 0705A - Doses from key} radlonuclldes released to alr (excluding lodine131) 1944-1981 + Report on lodine-131 doses, 1944-1991, due September 1993 and reschoduled to Fobruary 1994

- provided outline of this combined report to the TSP for review during the Arst week of August

\section{Milestone 07058 - Doses from Koy}

Radionucllde In Columbla River Water, 1950. 1991, due september 1993 and rescheduled to Fobruary 1994

- provided outline to the TSP for review during the nrst week of Augual

\section{Millestone 0705D - Natlve Amerlcan Phase I Doses, no due date}

- recelved data sets for tribal dose calculations from oix tribes. Dose calculations have been completed for the Umatilla. Spokane, Colville. and Kallopel tribes. On July 26, preliminary dose results for the Spokane Tribe were presented. along with an oral report of the findings. to the tribal council.

\section{Pathways and Dose Code Dovelopment and Documentation (Subtask 0702)}

- completed the code development activities. IInplementation of the DESCARTES and CIDER computer codes continued. Code developers continue to support the lesting activities. All formal tests are being completed under the Technical Integration Task. The HEDR confgu. matlon management plan is complete and is being unplemented. The CRD code has been written and submitted to the Technical Integration Task for the inal internal development review and formal testing. 


\section{Major Problem Areas or Changes and Actlon Taken}

The discussion of sensitivity/uncertalnty of the dose calculations, originally planned to appear in the model rellability report (Millestone 08038), will be incorporated Instead into the respective niver and air dose reports (Milestones 0705B and 0705C). In agreement with the TSP and CDC. the publication dates for these Milestone $0705 B$ and 0705C reports have both been rescheduled to February 1994. This timing allows the TSP more opportunity to review the validation test results prior to releasing nnal dose estimates to the public. These dowe estimates will be provided to the TSP for comment in conjunction with the TSP meeting presently scheduled for March 1994 . Depending on the extent of the comments, a delay in that meeting could delay the nnal publication of these dose reports.

\section{Variance}

The cumulattve cost underrun was caused by holding money in reserve for dose calculations. Preparation for those calculations will begin in September and the calculation work Itself in October.

\section{Planned Work for the Next Three Months}

- continue environmental accumulation and dose computer coding activities related to code testing (Sublask 0702)

- continue Independent teating of the environmen. tal accumulation and dose computer codes (Sublask 0702)

- continue planning and tool development for the dose calculations (Subtask 0705)

- continue Native Amertcan Interactlons needed for dose calculations (Subtask 0708)

- begin preliminary dose calculations for represen. tative individuals and sample HTVS Individuals (Sublask 0705) 


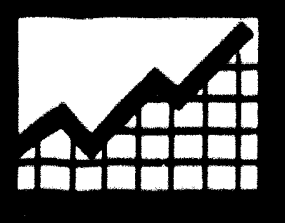

Task 08

\section{Statistics}

\section{Objectlve}

The objective of the task is to provide statistical support to other technical tasks and develop and apply senaltuitty and uncertainty analyses. Senaluvity analyses will be used to Identlfy parameters with the greatest influence on dose eatimates. Sensittvity analyses results will be used to focus resources where the benefi in terms of accurate dose estumates is greatest. Uncertainty analyses enable the project to determine the extent to which the accuracy and precision of the dose estimates are influenced by accuracy and preclolon in the input parameters.

\section{Progress}

\section{MIllostono 0s03A - Lottor Roport: Project Sonseltivhy/Uncertainty Analyale Plan, due Auguat 1092, roscheduled to Aprll 1903 and comploted (PNWD.2124 HEDR)}

- processed and sent to the TSP the report re. cetved from F. O. Hollman, consultant from the Center for Risk Analysis, dated June 14, 1893. on the writings and deliberations of the peer review panel that met May 24.25. 1993 in Richland. Washington to evaluate the senaluvity/ uncertainty analyuls plan

- facilitated F. O. Hollman's oral presentation of the peer revilew panel's report at the TSP meetung in Pout Falls, Idaho, on Juty 16, 1993

\section{Conoral Btatiotles 8upport (Bublask 0802)}

- provided support to the Source Terms Task staff to eatimate releases of radionuclides from Hanford reactors into the Columbla River

- prepared quality assurance (QA) documentation on river data statistical analyses

- conducted analyses of Columbla River nah and water data to estumate nah-to-water concentra. thon ratios

- provided statistical support to the Demography, Food Consumption and Agriculture Task atart to help plan the meeting with three milk distributJon experts on July 12-14, 1993

- prepared computer nle input to STRRM model

\section{Analysis of Model Rollabllity (Subtask 0803)}

- began conducting statuatical analyses for model validation activities, Including vegetation data and Oreen Run data

- met with members of the TSP and CDC to review and discuss validation activities

- conducted code verincation tesung of the STRRM. DESCARTES, and CIDER codes

- continued OA documentation of Inal computer runs of the RM code

- continued testing, verifying, and documenting the PILOT code. Errective the end of Auguat, the PILOT code work stopped. PILOT will be used for verincation rut will not be part of the turnover package to the CDC.

\section{Major Problem Areas or Changes and Action Taken}

A the result of a TSP decision, the more appropr. ate publication of the model reliability report information (Milestone 0803B) will be for the validation results to be published in a separate validation report (Milestone 0204C) and the discussion of sensitivity/uncertainty to be incorporated into the rtver and air dose reports (Milestones 0705B and 0705C).

Efrective Auguat 26, P. W. Eslinger is the new Statistice Task Leader. P. W. Eslinger is a - tallsticlan and computer code developer who jolned the HEDR Project last year to lead the alr 
pathways dose code recovery eftort. R. O. allbert. the former Statjstics Task Leader, will continue to revlew project documents and be avallable for consultation. In addition. J. C. Simpson. Analysis of Model Rellability Subtask Leader, will be leaving BNW effective October 12. 1993 but will complete her HEDR Project work with BNW on a subcontract.

\section{Varlance}

No significant cumulative variance.

\section{Planned Work for the Nexi Three Months}

- provide project-wide statistical support for data and information gathering, analysis, interpreta. tuon, and reporting

- asalst with validation studies
- assist with conducting uncertainty and sensitiv. ity analyses

- assist in the Writing of the dose reports (Milestones $0705 B$ and $0705 C$ ). Including uncertalnty and sensitivity analyses, and the validation report (Mllestone 0204C)

- Anlsh vertincation testing of computer codes

- Inish QA documentation on Columbla Ruver data statistical analyses

- Anlsh analyses of Columbla Rver Ash and water data to estimate nsh-to-water concentration ratios

- Anish documenting statistical analyses of diet information

- revise the lodine-131 Conversion Factor Report $(0802 \mathrm{~A})$ in response to CDC and TSP comments. if such comments are recelved 


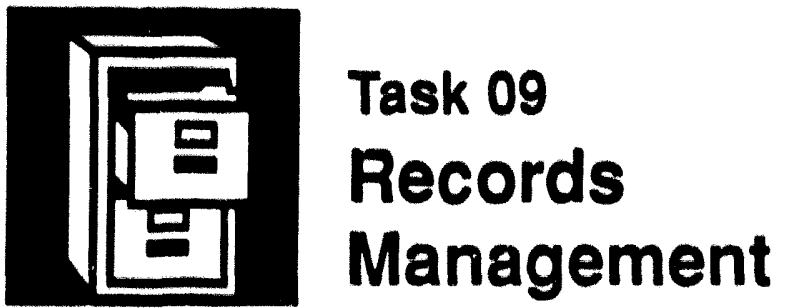

\section{Objective}

The objective of the Recurds Management Task is to provide storage and control of completed project records, maintain an automated inventory of all project documentation. and provide a reference service to project staff and the TSP.

\section{Progress}

- recetved project records from the HEDR Project

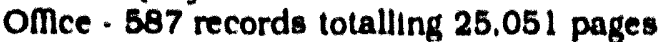

- vertfled, processed, and stored project records . 352 records totalling 16,420 pages

- transferred four packages of records to the U.S. Department of Energy RIchland Operations (RL) Public Reading Room - 20 records totalling 839 pages

- completed review and collection of the Demngraphy, Food Consumption, and Agriculture Task's records

- revised the RIDS to Include configuration management records and nle category changes identined during lask nle reviews. The configuration management category will have all the HEDR Project calculational tools. This "tool box" will form the basis of the technical turnover package to $\mathrm{CDC}$.

- met with C. W. Mlller, CDC, to discuss the records turnover package

- met with task leaders and other project staff to review task nles for compllance and collect completed records. Collected 35 boxes of records to be included in t'.e project flles as a result of this activity.

\section{Major Problem Areas or Changes and Action Taken}

None.

\section{Variance}

No signincant cumulative vartance.

\section{Planned Work for the Next Three Months}

- continue to process incoming project records

- continue to transfer processed HEDR Project records to the RL Public Reading Room

- complete changes to flle classincations as iden. Uned in the Quality Assurance Audu Report of the Hanford Environmental Dose Reconstruction Project, OHE-3, Audit A-92-20 (PNWD-2049 HEDR) 


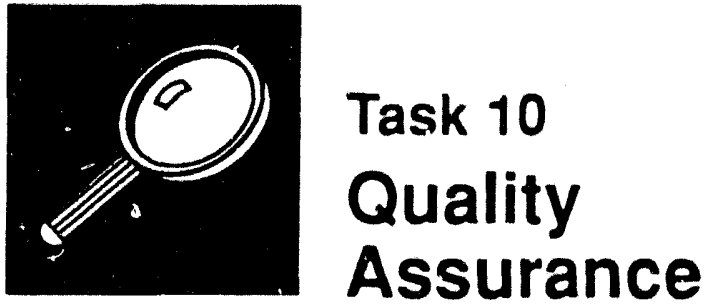

\section{Objective}

The objectuve of this task is to ensure continuous quality assurance (BA) support and coordination with all project tasks. This objective is met through the identincation and documentation of $Q A$ requirements in the form of a QA Plan and periodic monitoring of project activitles during the life of the project to ensure compliance with these requirements.

\section{Progress}

- reviewed and provided comments on the followIng reports:

\section{HEDR Software Connguration Management Plan (HEDR-TT'-9) \\ - HEDR Model Validation Plan (PNWD-2156 HEDR}

\section{HEDR Technical Revlew Process (HEDR-TP-5) \\ Document Preparation Plan (1'NWD-2170 HEDRI}

Fuel-Element Fallures in Hanford Single-Pass Reactors, 1944.1971 (PNWD-2161 HEDR)

lodine-131 in Vegetation Collected Near the Hanford Site: Concentration and Count Data for 1948-1951 (Milestone 0502B)

Conversion and Correction Factors for Historical Measurement of lodine-131 in Hanford-Area Vegetation, 1948-1951 (Mile stone 0502B)

- drcumented progress on the HEDR Project records control issues identuned during the 1992 annual audit of the HEDR Project. Developed an action plan to address these records issues. Including a schedule for processing Phase I records. Provided monthly progress reports to the audil leam.

- trained the HEDR Project staff who are responsible for conflguration management on the HEDR Software Configuration Management Plan. The plan Includes the procedures for maintalning and documenting all project software: and data. Several modincations are being suggested to streamline the approval process. Also provided a one-day workshop on the Software Configuration Management Plan to members of CDC.

- attended the Technical Steering Panel meeting in Post Falls, Idaho, and updated the Technical Integration/Quality Assurance Subcommittee on the recent $Q A$ activities

- prefiared the HEDR Quarterly Survellance Plan for the fourth quarter of FY 1993 and submitted the results of the survelllances completed in the third quarter

- completed drafing the HEDR-TP-8, the HEDR Action Tracking System Procedure, and recelved Project Oflice review comments

- provided Software QA support in the following areas:

- continued nnal internal development reviews of the SHUFFL. AGGREGATE. DESCARTES, and CIDER computer codes

- developed the Software Requirements Form and Independent Technical Review for tesung STRM

- revised the Software Requirements Form for RATCHET

- cleveloped the Software Requirements Form and Independent Technical Review for the Source Terms Task

- partuclpated in the review of the dose codes 


\section{Major Problem Areas or Changes and Action Taken}

None.

\section{Variance}

No significant cumulative variance.

\section{Planned Work for the Next Three Months}

- continue performing oversight activities to check for compliance to HEDR Project technical, QA. and data quality objectives (DQO) requirements.
- Analize the decision plan (HEDR-TP-3) and implement the technical procedure.

- distribute HEDR Conference Record (HEDR-TP7) and begin utllizing the procedure to document declsions and actions resulting from HEDR meetings

- finalize HEDR Action Tracking System (ATSHEDR-TP-8) and begin utilizing the system to track the results of the HEDR Project technical stafl meetings 


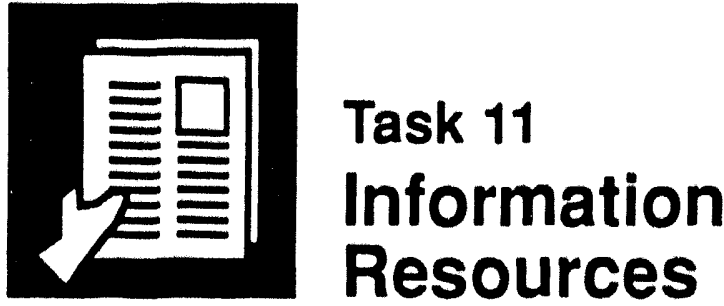

\section{Objective}

The objecttve of the Information Resources Task is to work with other tasks to meet information needs. Including ensuring that all data referenced in the reports are publicly avallable and establishing a microcomputer-based tracking system for ready retrleval of historical information.

\section{Progress}

- published the letter report, Fuel-Element Fallures in Hanford Single.Pass Reactors 1944-1971 (PNWD-2161 HEDR)

- arranged review of classifed documents by TSP members, G. G. Caldwell, M. L. Blazek, and P. D. MCGavran, and a review of unclassifled documents by TSP member, N. J. Germond, at the Records Holding Area in Richland, Washington. These reviews are part of the TSP Docu. ment Review Plan.

- responded to questions from the CDC regarding the denlal of a TSP member's access to certain classined documents

- assisted in arranging a review of unclassifled documents by N. J. Germond, TSP, at the Records Holding Area in Rlchland, Washington

- pulled and provided for review several hundred documents for TSP members B. Shleien and M. A. Robkin. Copies of documents of interest were duplicated and provided.

- declassifled 116 Hanford Site originated documents, one of which was of potential interest/ use to the HEDR Project. Table 11.1 shows the status of declassification to date.

- verifled bibliographic references In HEDR reports

- provided the RL Public Reading Room with 19 documents (1.172 pages) of potential interest/ use in the HEDR Project. A title listing of these reports is given in Appendix B.

\section{RL Public Reading Room Activity}

During June, July, and August, the RL Public Reading Room had 16 HEDR patrons and distributed 63 HEDR reports.

\section{Major Problem Areas or Changes and Action Taken}

None.

\section{Variance}

No signlficant cumulative varlance.

\section{Planned Work for the Next Three Months}

- assist M. A. Robkin. TSP member, with InformaUon development of radionuclide releases from facilltles other than chemical separations plants and reactors located on the Hanford Site

- support visiting TSP members during document search and review efforts

- attend the TSP Public and Communications Subcommittee meetings in October in Pasco. Washington 
Table 11.1. Declassification of Hanford-Site-Originated Documents

Documents Declassined

March 1987 - Seplember 1987 (FY 1987)

October 1987 - September 1988 (FY 1988)

October 1988 - September 1989 (FY 1989)

October 1989 - September 1990 (FY 1990)

October 1990 - September 1991 (FY 1991)

October 1991 - September 1992 (FY 1992)

October 1992 - August 1993 (FY 1993)

TOTAL (March 1987 - August 1993)
Hanford
Historical

35

52

186

455

1323

2862

860

5773
HEDR.

Related ${ }^{(0)}$

27

37

177

236

599

554

86

1716

(a) Reported in HEDR quarterly reports and Included in a HEDR master listing in the RL Public Reading Room. Some of these are from the list requested by the TSP and the public. 


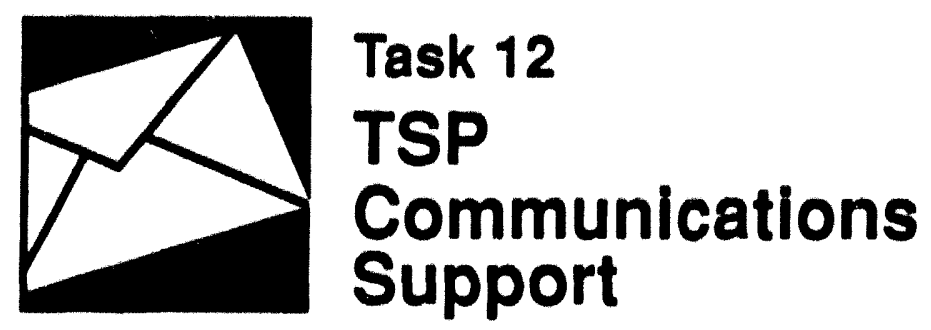

\section{Objective}

The objectuve of this task is to assist the TSP in developing competent communications strategles to further establish an efrective, informative dialogue with interested audiences, provide public and media relations support, and manage activities that foster a better understanding of the HEDR process and Its progress.

\section{Progress}

- drafted improved procedural guldelines, in support of DOE. which permit TSP members better access to documents of interest or poten. Ual use to the HEDR Project

- coordinated planning with Cable News Network (CNN) reporters. TSP Communications Subcommittee members. and BNW staft to videolape various HEDR Project activities in the development of a story about Hanford past, present. and currently conducted studies

- provided graphics materials to TSP Communicatlons Subcommittee staff which specilles the HEDR Project study area for use in development of information materials

- provided photo portralts of six TSP members for use in the upcoming quarterly newsletters

- provided review comments to TSP Communica. Uons Subcommittee staff for development of a computer modeling fact sheet

- provided reports of interest to the HEDR Project to M. A. Robkin at his request
- attended the TSP Public and Communications Subcommittee meeting in Post Falls, Idaho

- provided information and contact numbers for the HEDR Project and HTDS to N. Rob, Spokane. Washington, and M. Turley, Pasco. Washington.

\section{Major Problem Areas or Changes and Action Taken}

None.

\section{Varlance}

No significant cumulative variance.

\section{Planned Work for the Next Three Months}

- attend the TSP Public and Communications Subcommitlee meetings in October in Pasco, Washington

- assist the TSP Communications Subcommiltee staft in reviewing materlals belng developed for public distribution 


\section{Appendix A}

Milestones, Schedule, and Costs 


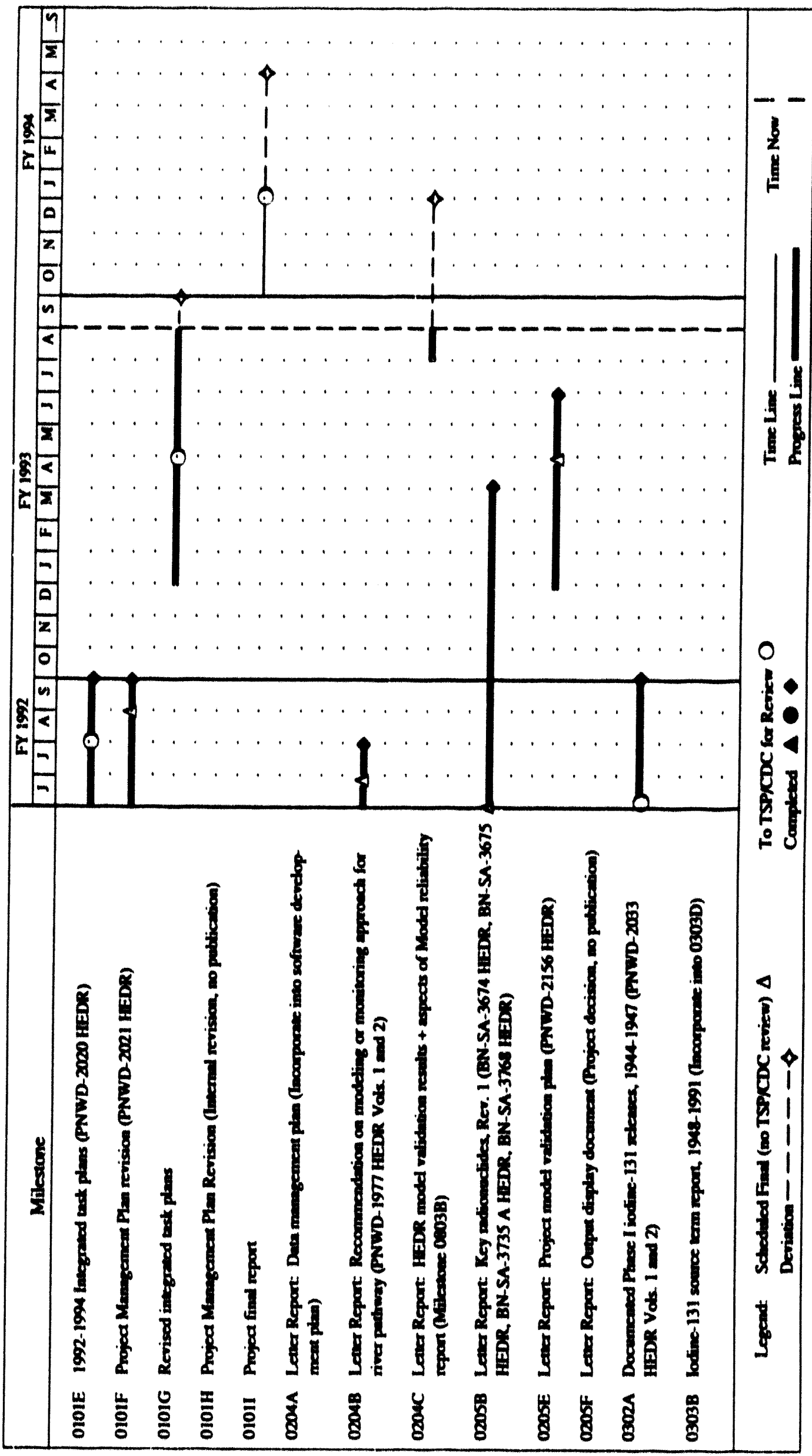

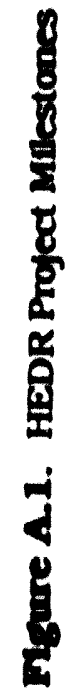

A. 1 


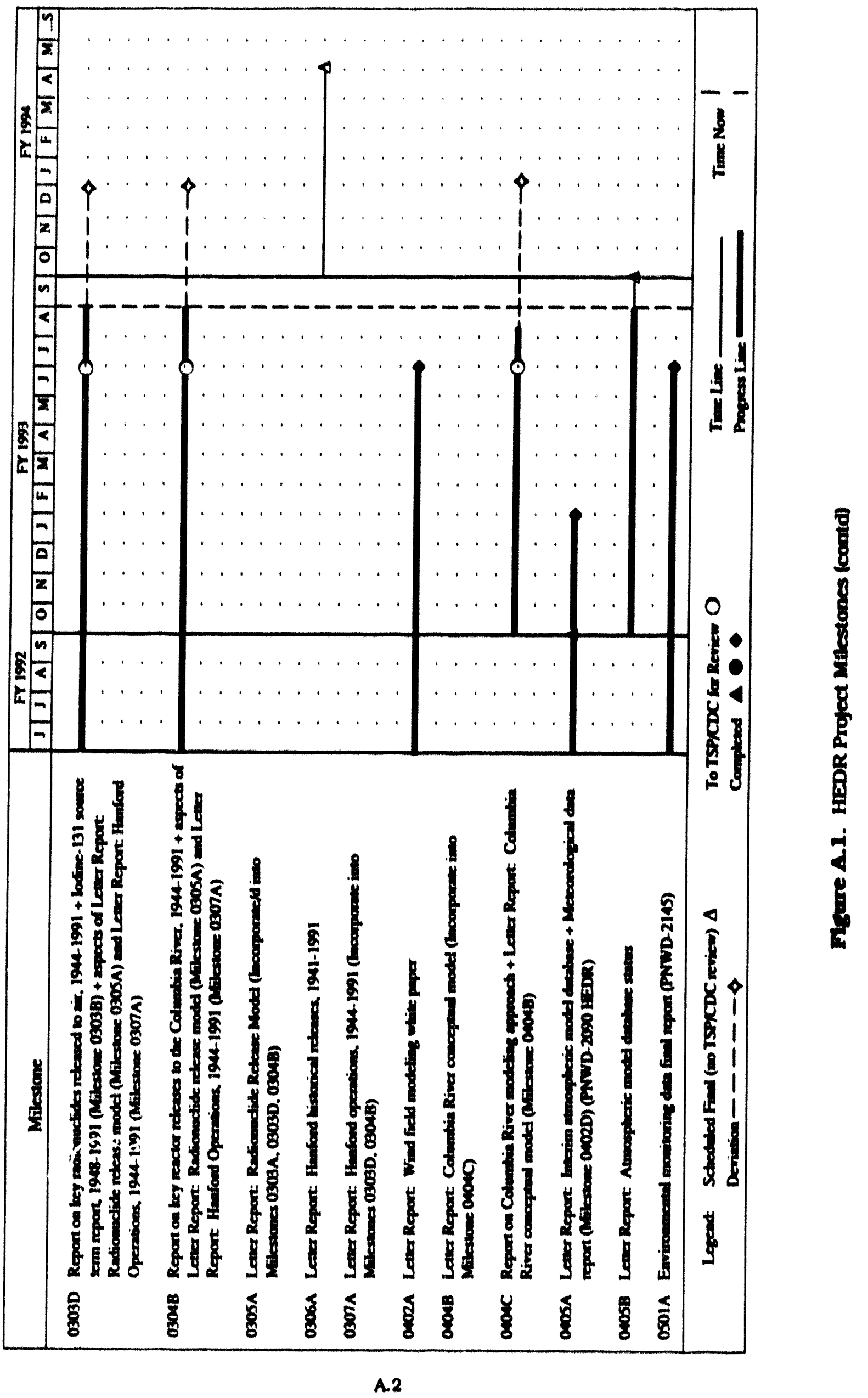




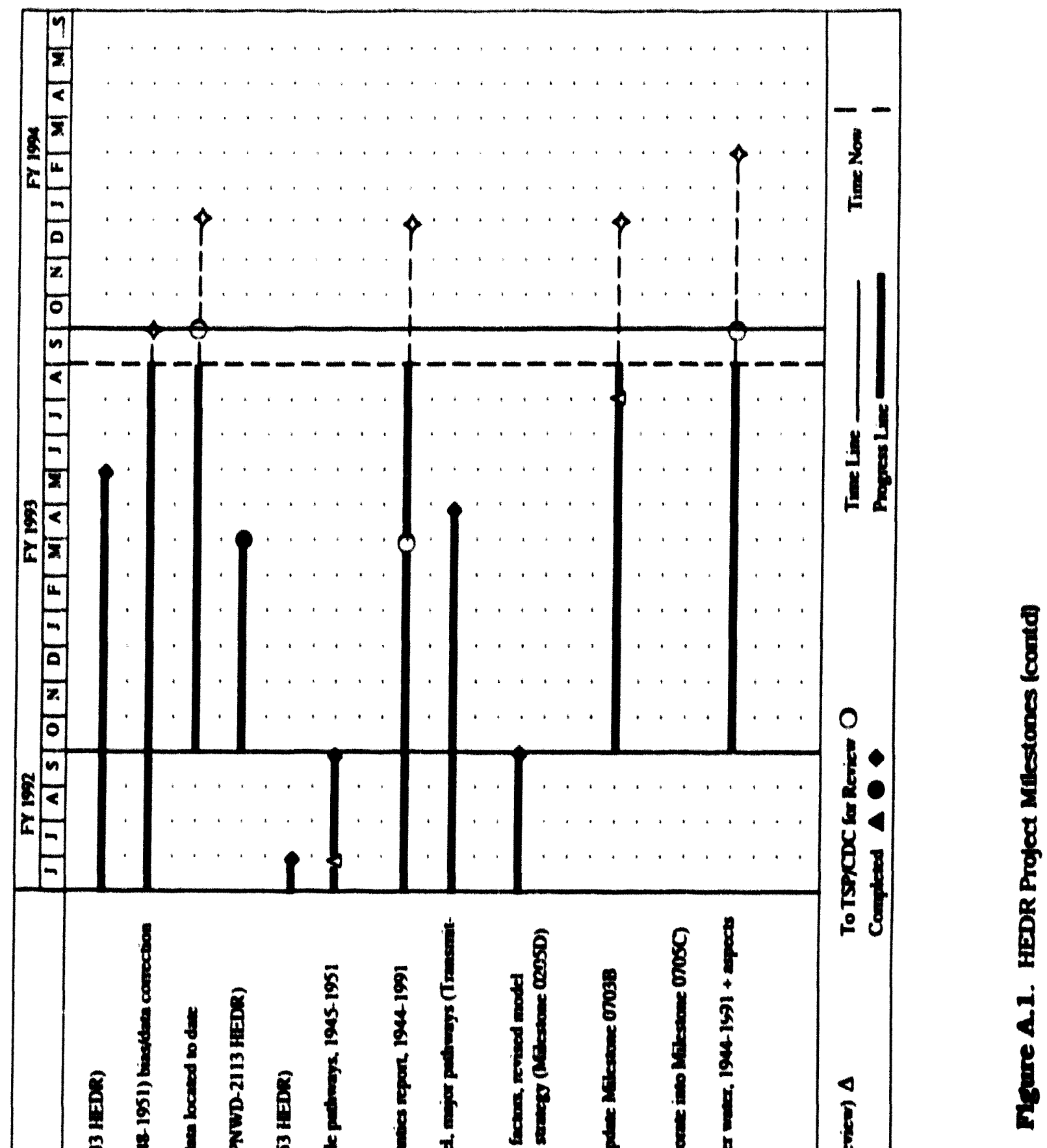




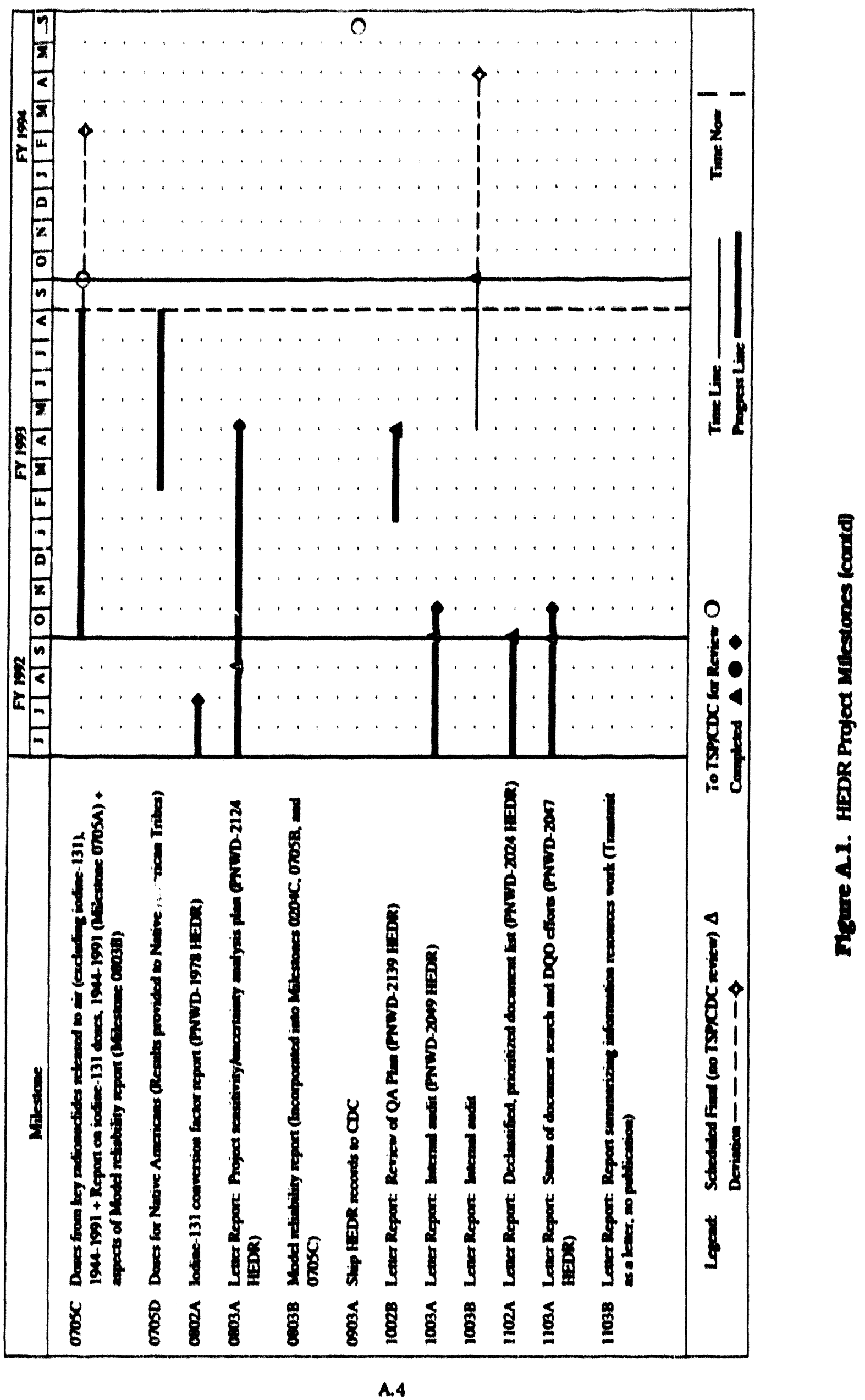




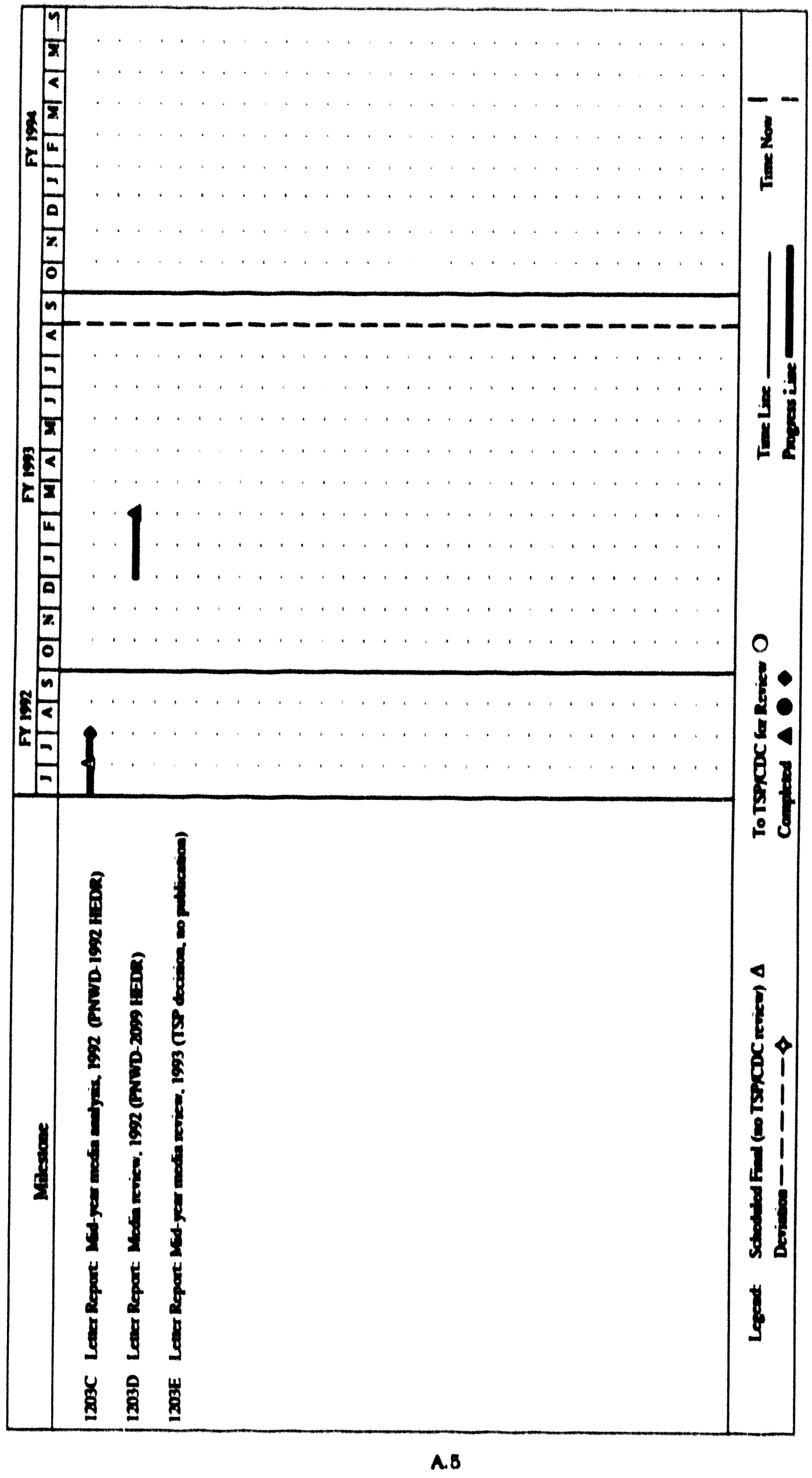

8
8
8
8
8
8
8
8
4
4
4 


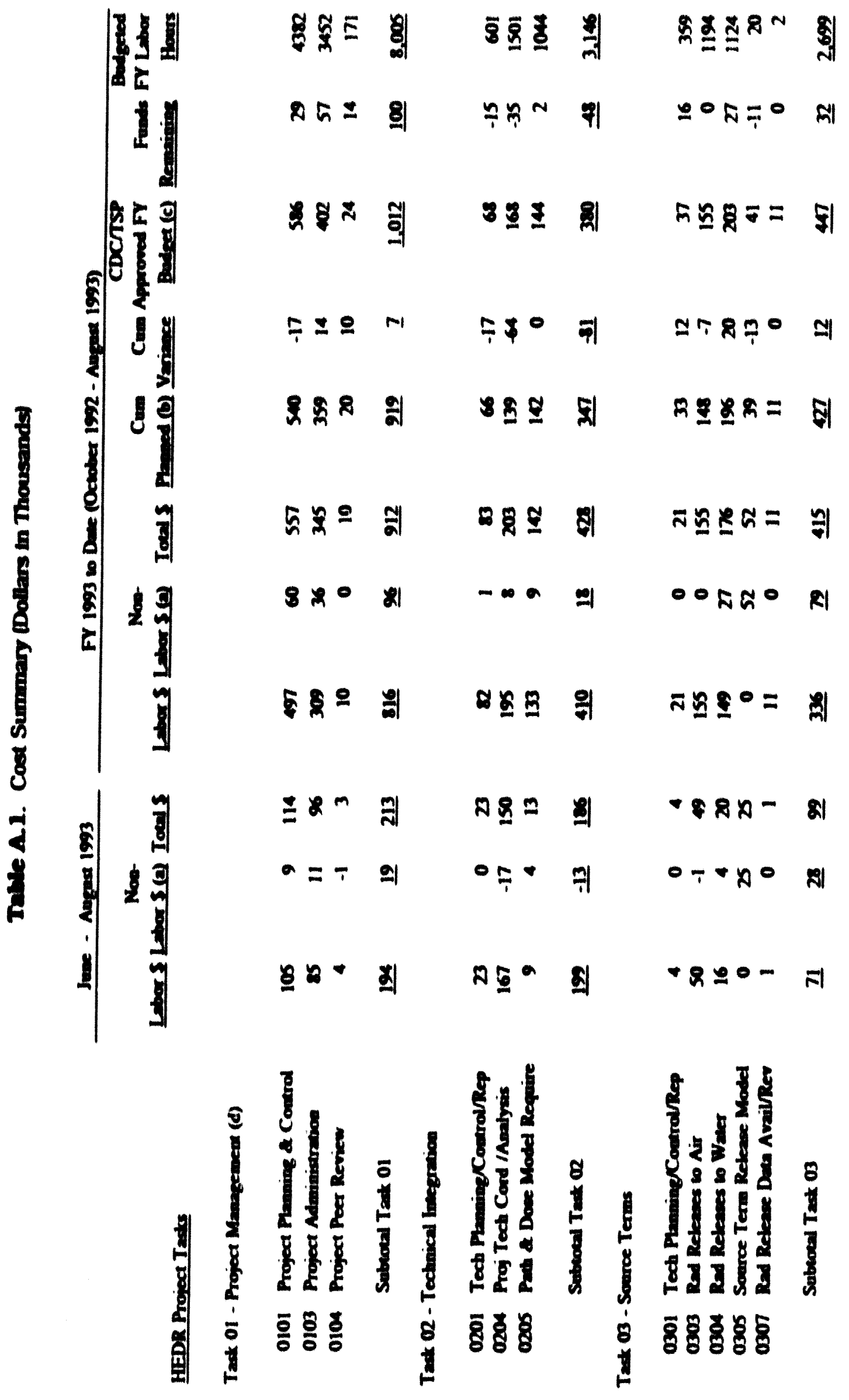




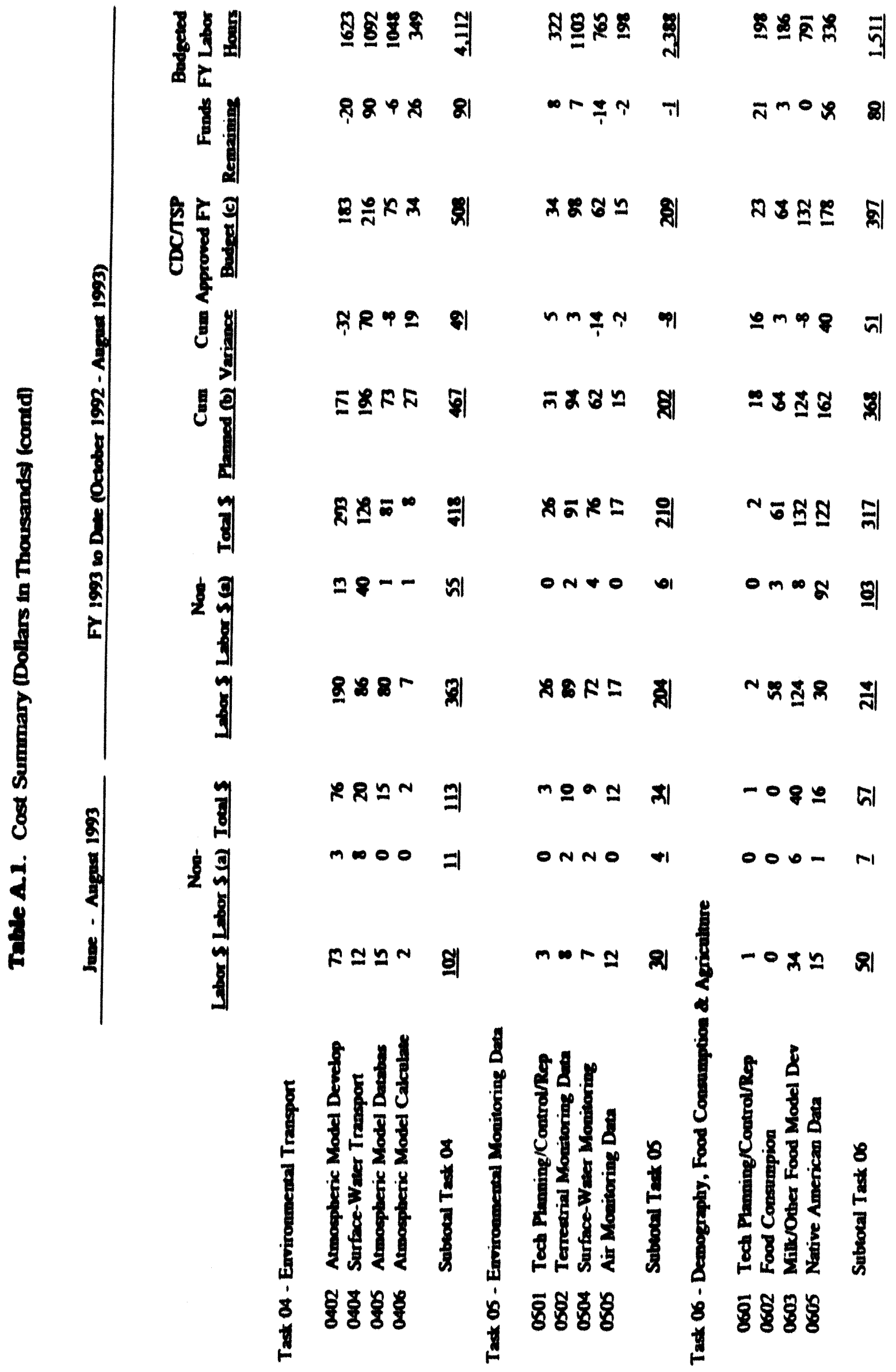




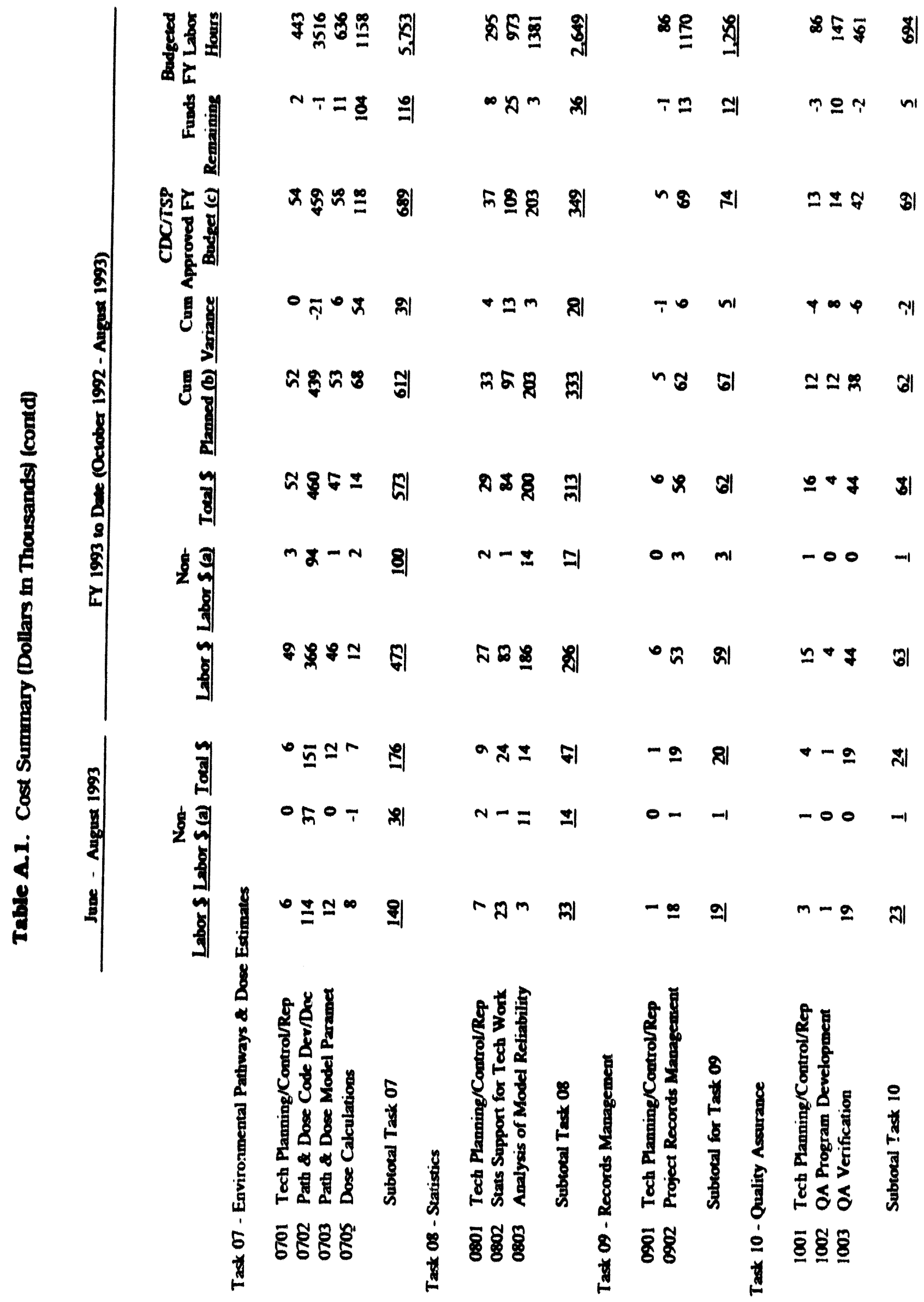




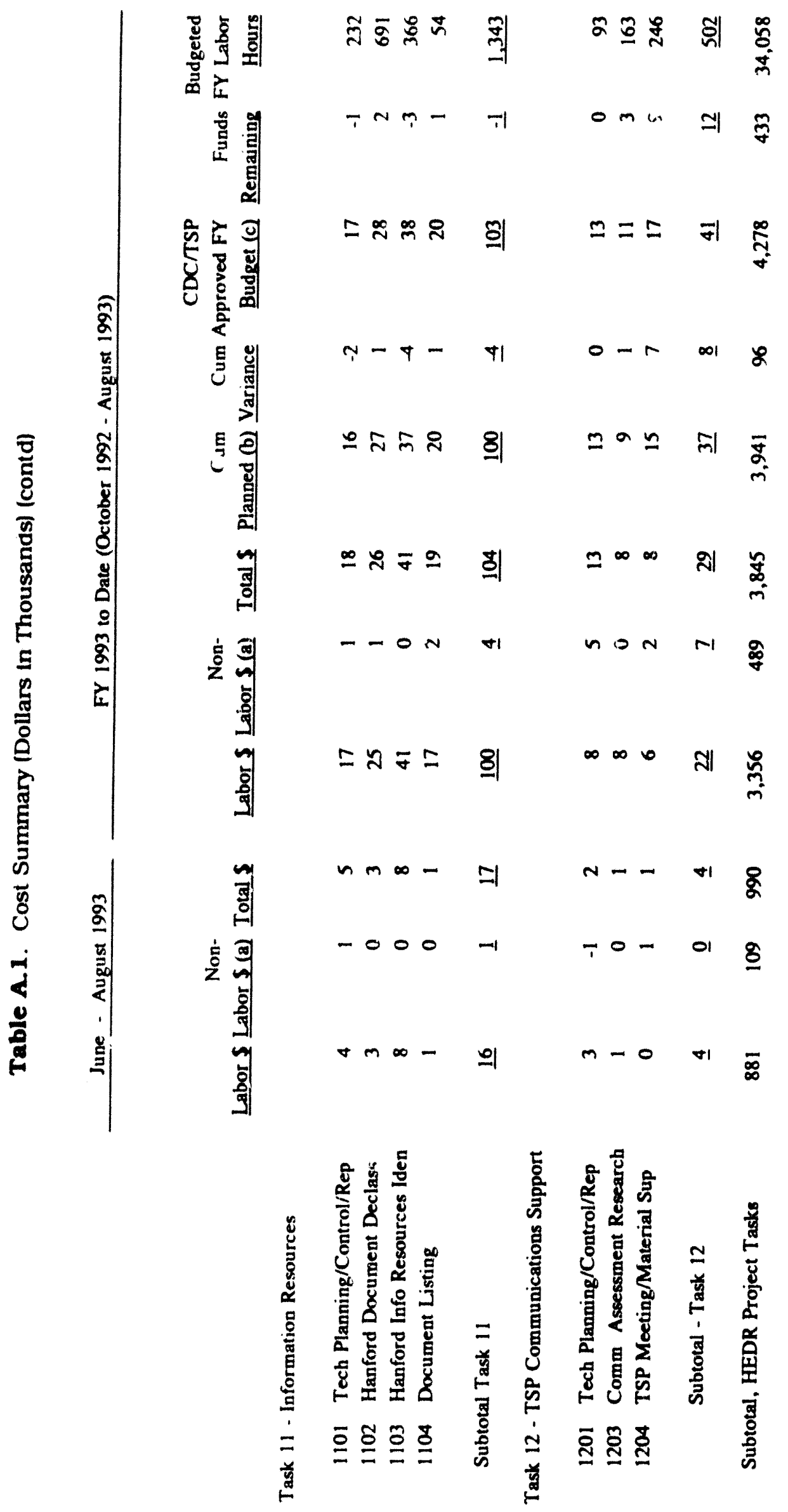



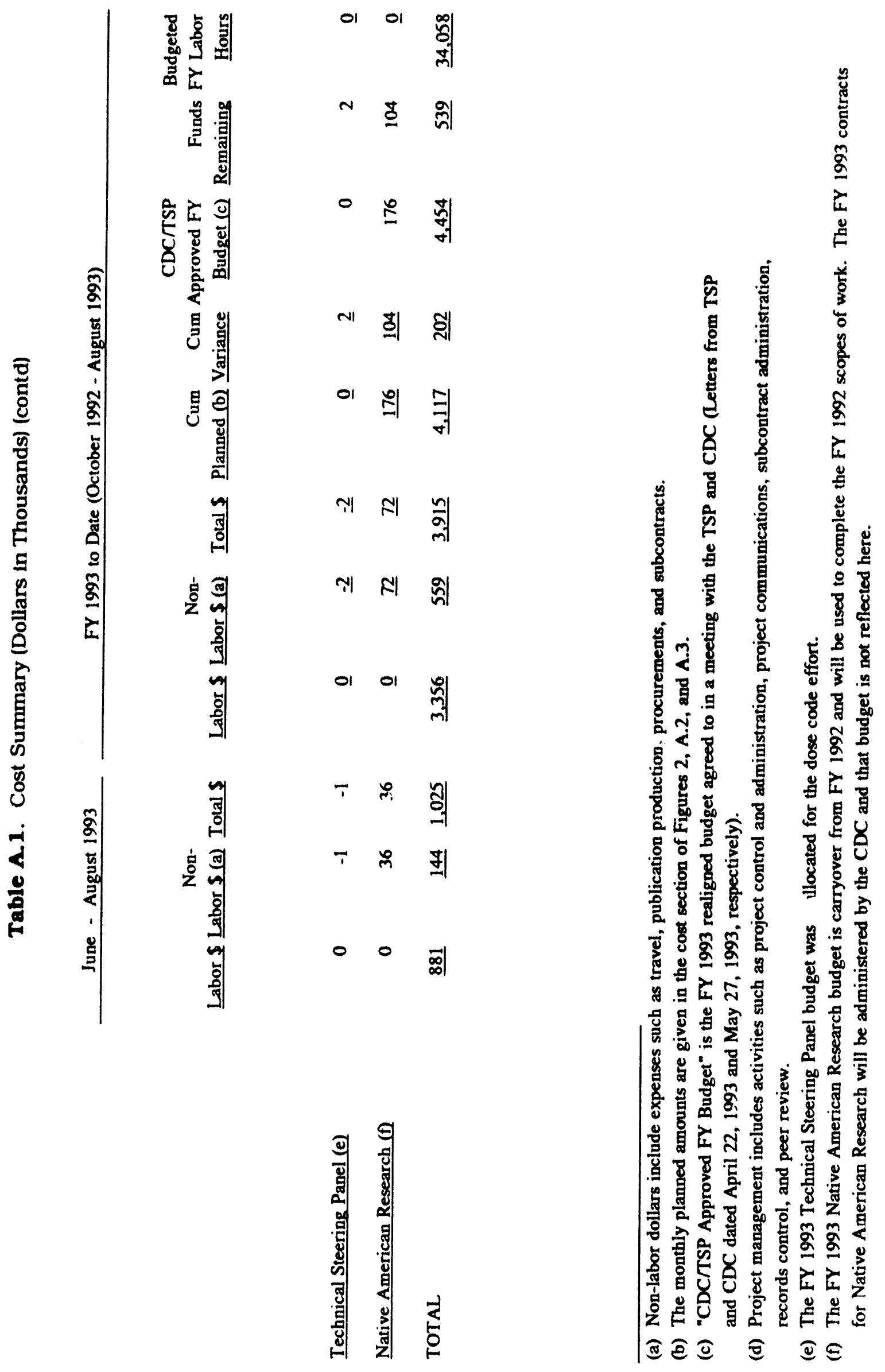


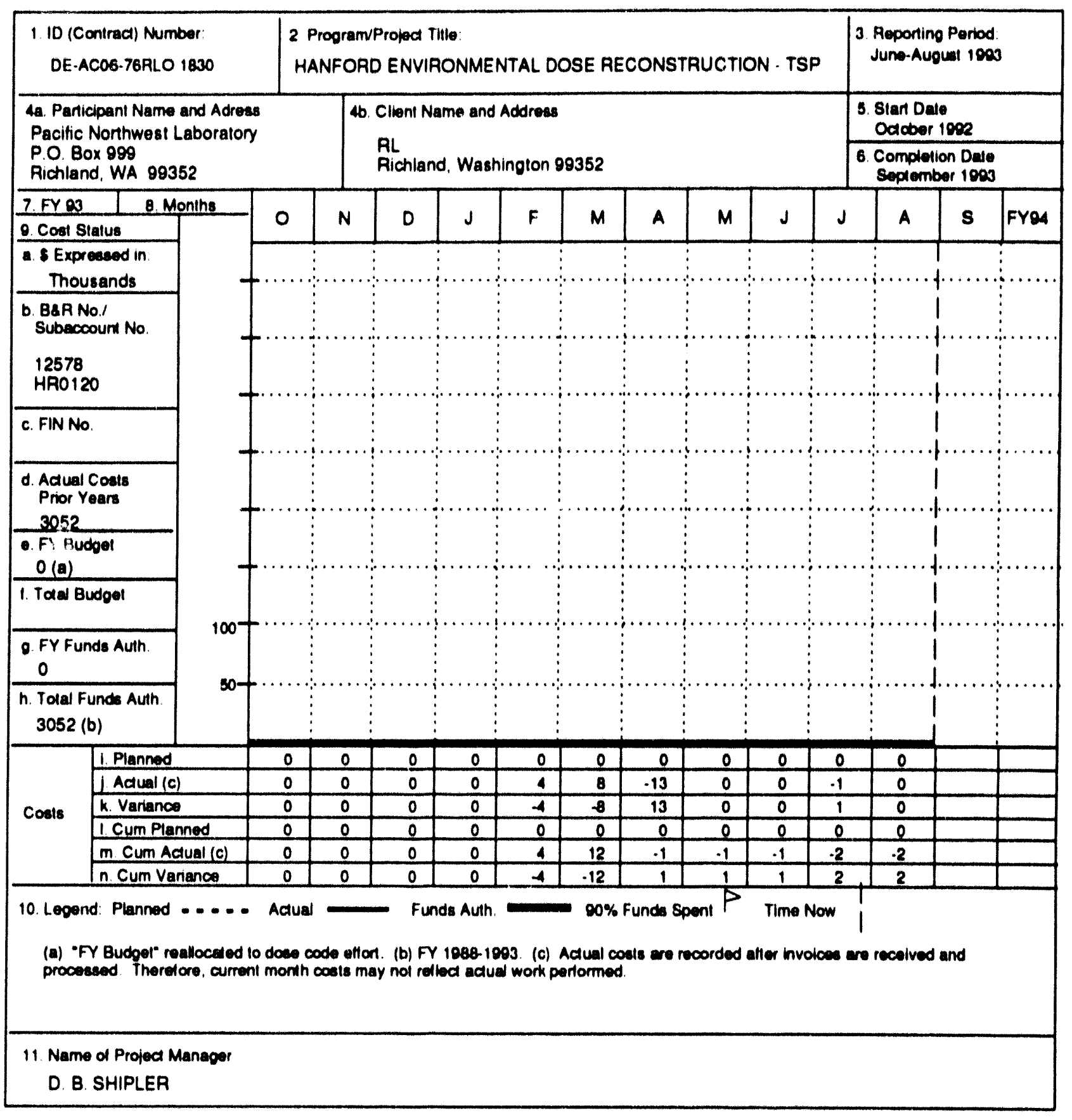

Figure A.2. Techndcal Steering Panel Budget Status 


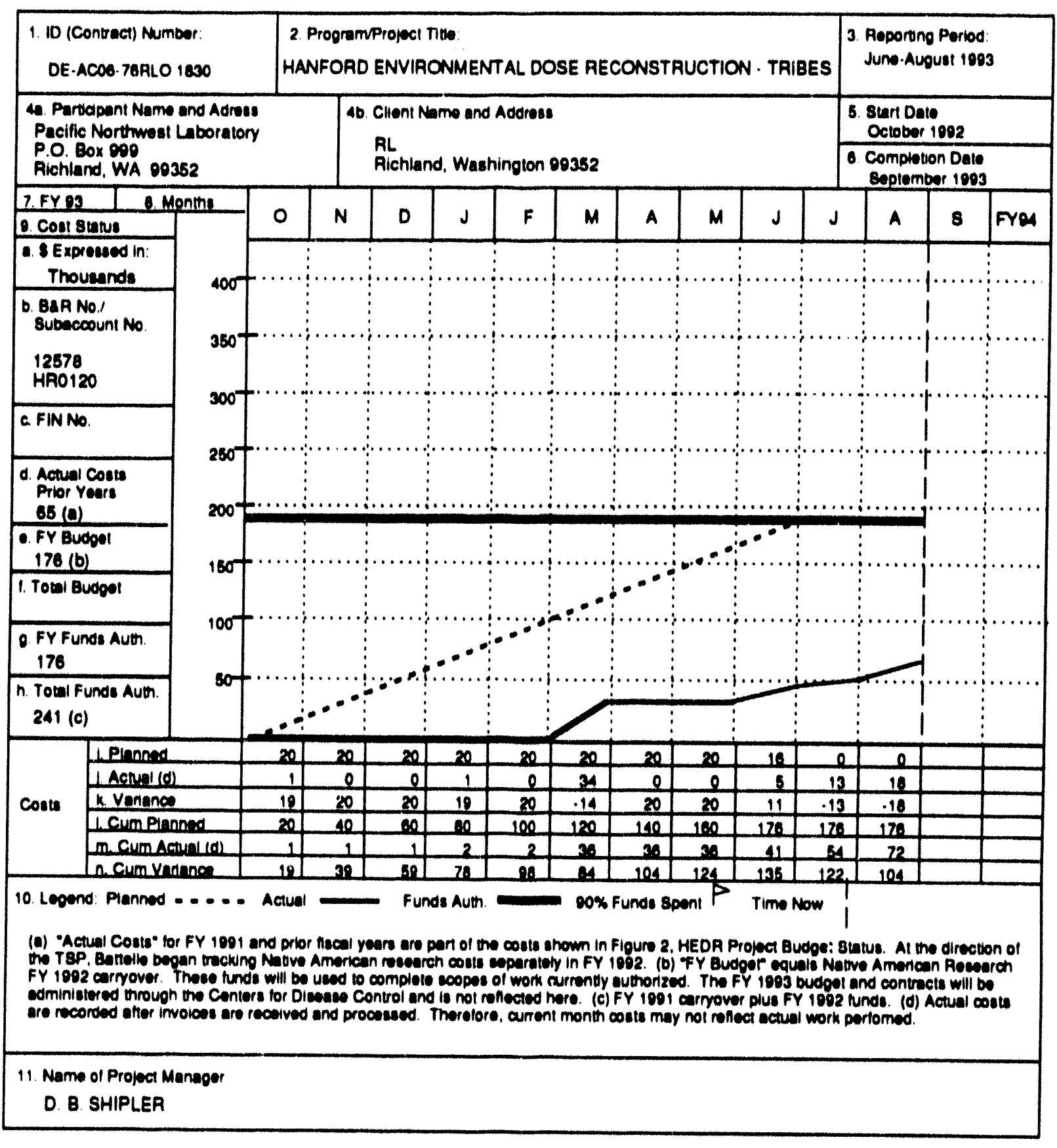

Mgure A.3. Native American Research Budget Status 
Appendix B

Hanford-Site-Originated Documents of Potential Interest/Use to the HEDR Project Placed in the RL Public Reading Room

During June-August 1993 


\section{Appendix B}

\section{Hanford-Slte-Originated Documents of Potential Interest/Use to the HEDR Project - Placed In the RL Public Reading Room During June-August 1993}

HW.73636

HW.75045

HW. 89093

HW.SA.2730

PNL-8308

PNL-8397

PNWD-1880-11 HEDR

PNWD-2145 HEDR

PNWD-2148 HEDR

PNWD-2156 HEDR

PNWD-2161 HEDR

BN-SA-3799 HEDR

PWM-542

RL.SEP.855

WHC-EP-0475-1

WHC-MR-0388

WHC.SP.0665-2

WHC.SP.0665-3

UN1.0960
FPD Facllitles - Radiological Status. 5 p.

$05 / 10 / 62$

Calculated Fission Product Release from PRTR Rupture. 12 p.

$09 / 28 / 62$

Vegetation Corrections for 1.131. 2 p.

$12 / 07 / 4 \theta$

Dosimetry Investigation of the Recuplex Accident. $32 \mathrm{p}$.

$08 / 22 / 62$

Characterization of Radiation Environments at Selected Pacific Northwest Laboratory Facillties. 87 p.

$10 / 08 / 92$

$08 / 09 / 66$ Public Avallability. 2 p.

Hanford Environmental Dose Recunstruction Project Quarterly Report April-May 1893. 50 p.

$05 / 31 / 93$

$06 / 14 / 83$

Phase I. Summarles of Radionuclide Concentration Data for Vegetation. River Water, Drinking Water, and Fish. 128 p.

$06 / 01 / 93$

A Review of Wind Fleld Models for Atmosphertc Transport. $30 \mathrm{p}$.

06/01/83

$07 / 01 / 93$

1944-1971. $300 \mathrm{p}$.

$05 / 01 / 83$

Software Requlrements Specincations for Columbla River

Pathway: Source Term. River Transport Environmental

Accumulation and Dose Models. 8 p.

Power Level History of Single.Pass Ruchland Reactors. 4 p.

$01 / 30 / 73$

Historical Events of the Chemical Processing Department. 20 p.

$11 / 12 / 68$

Facillty Emuent Monitoring Plan for the Fast Flux Test Facllity. $105 \mathrm{p}$.

$11 / 01 / 92$

Compllation of Historical Information of 300 Area Facilities and Actuvitles. 309 p.

$12 / 04 / 82$

Environmental Radiological Survey Summary 100, 200, 300. and 600 Areas. $28 \mathrm{p}$.

$10 / 16 / 91$

Quarterly Environmental Radiological Survey Summary, 32. p. 01/01/92

Radionuclide Discharge to the Environment Following January 1978 Fuel Cladding Fallure. $4 \mathrm{p}$.
$02 / 20 / 78$ 


\section{Appendix C}

\section{HEDR Documents to the TSP - June-August 1993}

A complete llating will appear in the september-November quarterly report. 


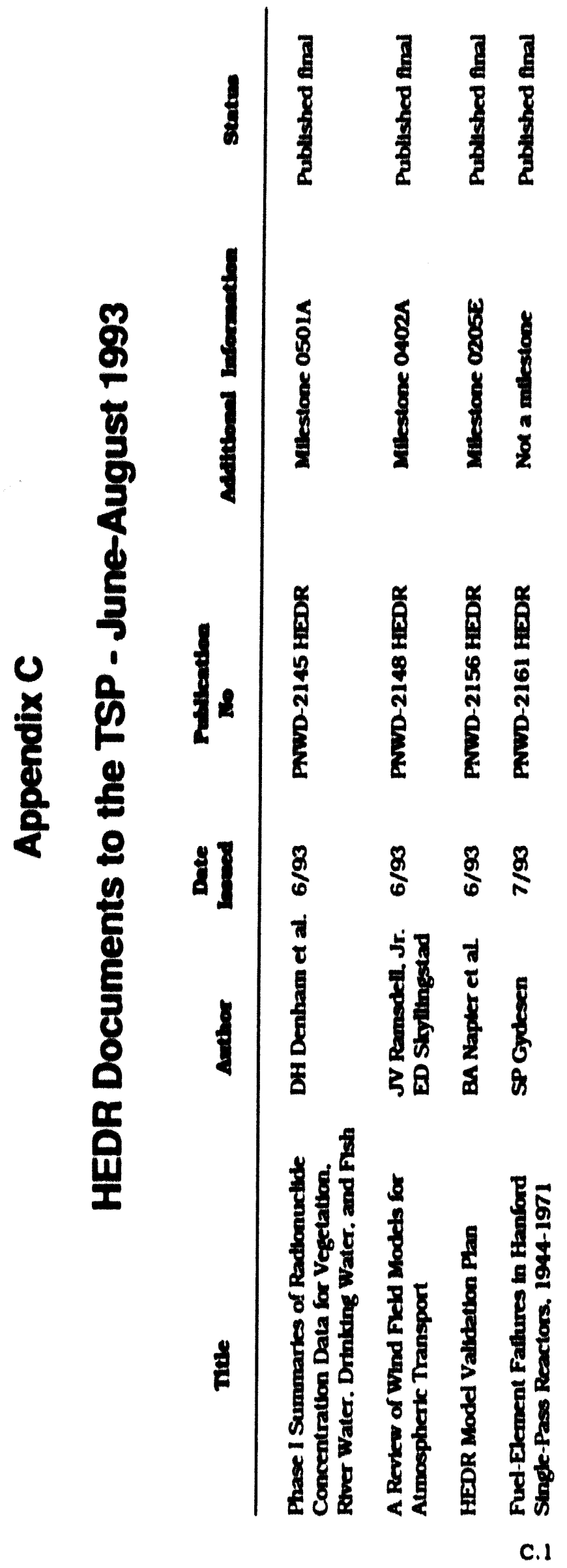




\section{Appendlx D}

\section{HEDR Presentation Handouts to the TSP - June-August 1993}

A complete lloting will appear in the Eeptember-November quarterly report. 


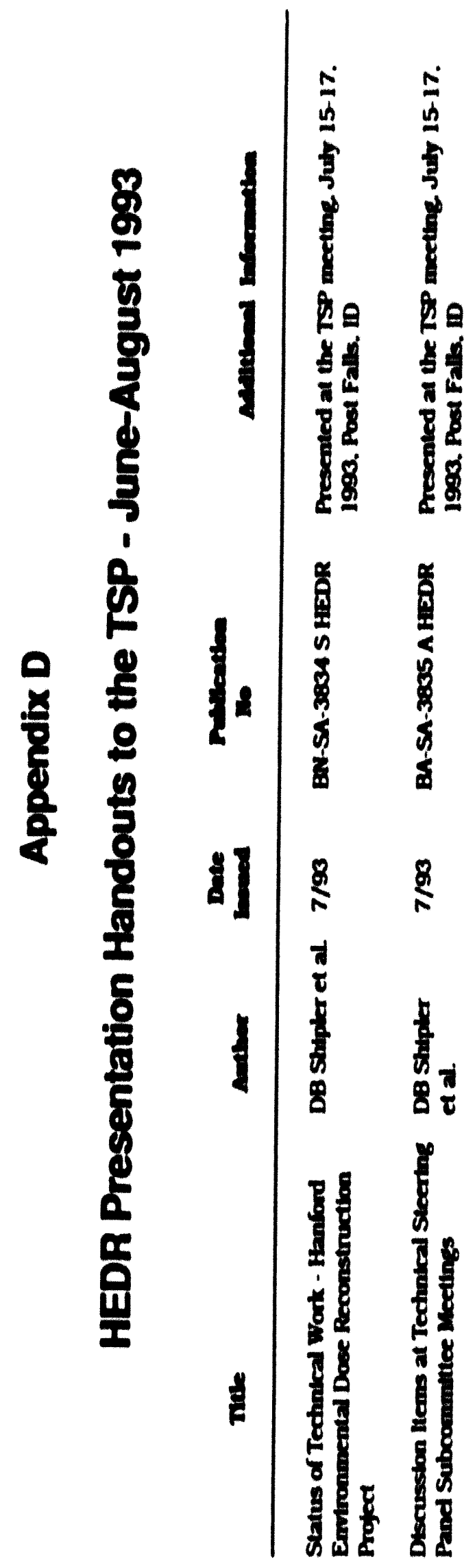

D.I 


\section{Appendlx E}

\section{HEDR Open-Literature Publications and Presentations - June-August 1993}

Thls appendis lists publleations thut precent appects of dese reconotruotlon In the open solentife Uternture. ToP approval is not requlred. A complete Uoting will appear In the Soptember-November quarterly report. 


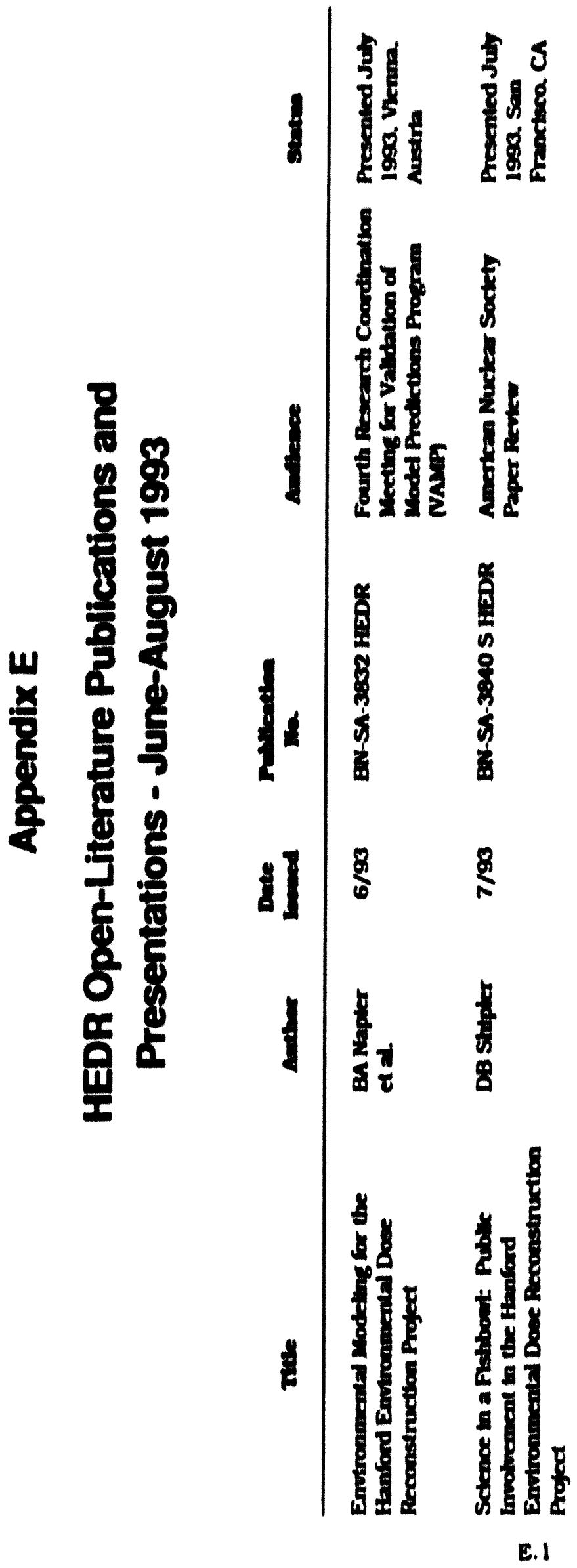


Appendix F

Communications Log - June-August 1993 


\section{Appendlx F}

\section{Communications Log - June-August 1993}

\begin{tabular}{|c|c|c|c|}
\hline $\begin{array}{l}\text { Initlated Dy/ } \\
\text { Anilintlon }\end{array}$ & $\begin{array}{c}\text { Contaot/ } \\
\text { Anellation } \\
\end{array}$ & Type & Oubjeot \\
\hline \multicolumn{4}{|l|}{ June 1008} \\
\hline B Aripa/CT & EB Lebow/BNW & Phone & Data summary \\
\hline WA Bluhop/TSP & SM FInch/BNW & Phone & $\begin{array}{l}\text { No cout tume extenslons for NP, WS, } \\
\text { and Yakuma tribes }\end{array}$ \\
\hline WA Blahop/TSP & EB Llebow / BNW & Phone & $\begin{array}{l}\text { Status update on tribal work: } \\
\text { meeting scheduled for } 6 / 15\end{array}$ \\
\hline ML. Blazek/TsP & OL Harvey/BNW & Phone & $\begin{array}{l}\text { Review of classined documents and } \\
\text { boxes in early July }\end{array}$ \\
\hline K Charlee/TSP start & SM Finch/BNW & Phone & $\begin{array}{l}\text { Tupes from uncertainty/eenaltivity } \\
\text { peer review }\end{array}$ \\
\hline K Charlee/TSP staft & OL Han ey/BNW & Phone & $\begin{array}{l}\text { Unclasalned documents at Records } \\
\text { Holding Area: arrangements } \\
\text { requlred to prepare for unclasolned } \\
\text { and classined documents review in } \\
\text { early July: llat of clasalned docu. } \\
\text { ments requeated for review and } \\
\text { TSP's preferred method }\end{array}$ \\
\hline o Comba/Tsp Start & SM Finch/BNW & Phone & $\begin{array}{l}\text { Llat of work completed: tapes and } \\
\text { notes from uncertalnty/oensituvity } \\
\text { peer review }\end{array}$ \\
\hline a Comba/Tsp staft & OL Harvey/BNW & Phone & $\begin{array}{l}\text { Portralts for use in the quarterly } \\
\text { newaletter }\end{array}$ \\
\hline SM Finch/BNW & $\begin{array}{l}\text { K Charlee/TSP } \\
\text { Staft }\end{array}$ & Phone & $\begin{array}{l}\text { Tapes from uncertainty/wenaltivity } \\
\text { peer review }\end{array}$ \\
\hline R Haber/Attorney & SP Oydesen/BNW & Phone & $\begin{array}{l}\text { Documentu and matertals regarding } \\
\text { the Project }\end{array}$ \\
\hline OL Harvey/BNW & ML. Blazek/TSP & Phone & $\begin{array}{l}\text { CNNa interest in reporting on } \\
\text { HEDR activities in early July: } \\
\text { Involvement in CNN television } \\
\text { network reporting of the HEDR } \\
\text { Project }\end{array}$ \\
\hline P Houck/CDC & EB Llebow/BNW & $\begin{array}{l}\text { Phone, } \\
\text { Fax }\end{array}$ & $\begin{array}{l}\text { Colville population data and sample } \\
\text { alze }\end{array}$ \\
\hline TA Ikenberry/BNW & B Aripa/CT & Phone & Tribal food consumptlon data \\
\hline
\end{tabular}




\begin{tabular}{|c|c|c|c|}
\hline $\begin{array}{l}\text { Initiated By/ } \\
\text { Afriliation }\end{array}$ & $\begin{array}{l}\text { Contact/ } \\
\text { Amfliation }\end{array}$ & Type & Subject \\
\hline TA lkenberry/BNW & WA BIshop/TSP & Phone & $\begin{array}{l}\text { Tribal dose estimates; general } \\
\text { population reference Individual } \\
\text { dose calculations }\end{array}$ \\
\hline TA lkenberry/BNW & MD Sequochs /YIN & Fax & Tribal food consumption data \\
\hline TA lkenberry/BNW & D Emst/ST & Phone & $\begin{array}{l}\text { Tribal dose estimates; Inittal dose } \\
\text { calculations }\end{array}$ \\
\hline TA Ikenberty/BNW & JR WIlkInson/UT & $\begin{array}{l}\text { Phone. } \\
\text { Fax }\end{array}$ & Tribal dose estimates \\
\hline EB Llebow/BNW & B Amundson/HTDS & Fax & Summary of $6 / 9$ meeting \\
\hline EB Luebow/BNw & $\begin{array}{l}\text { B Amundson/HTDS } \\
\text { H Schuster/Consultant } \\
\text { DE Walker/TSP }\end{array}$ & Fax & Summary of $6 / 15$ meeting \\
\hline EB Llebow/BNW & B Baker/KT & Phone & Need clariflcation on data submittal \\
\hline EB Lebow/BNW & WA Bishop/TSP & Phone & $\begin{array}{l}\text { Status update on tribal work; agenda } \\
\text { for July NAWG meetlng }\end{array}$ \\
\hline EB Llebow / BNw & V Bowman /KT & Phone & Questlons regarding data summary \\
\hline EB Luebow / BNW & D Powaukee/NP & Phone & Status update on tribal work \\
\hline EB Lebow /BNW & M Queahpama/ws & Phone & $\begin{array}{l}\text { Appointment to review work status: } \\
\text { status update on data collection }\end{array}$ \\
\hline EB Llebow/BNW & M Squeochs $/ \mathrm{YIN}$ & Phone & Appointment to review work status \\
\hline EB Luebow / BNW & DE Walker/TSP & E-Mall & Additional data on river pathway \\
\hline D Mayo/HHIN & SM Finch/BNW & Phone & $\begin{array}{l}\text { Information on avallable HEDR } \\
\text { documents }\end{array}$ \\
\hline PD MCGavran/TSP & SM Finch/BNW & Phone & $\begin{array}{l}\text { Request for a document: document } \\
\text { review; whole body count }\end{array}$ \\
\hline K Niles/TSP Stall & GL Harvey/BNW & Phone & $\begin{array}{l}\text { Canadian Broadcasting Corporation } \\
\text { news team to use TSP videotape in } \\
\text { documentary on Hanford: graphics } \\
\text { materials of study area: potentlal } \\
\text { support required in the development } \\
\text { of information materials leading up } \\
\text { to the first of the calendar year }\end{array}$ \\
\hline D Powaukee/NP & EB Llebow/BNW & Phone & Tribal data summary \\
\hline B Shlelen/TSP & DB Shipler/BNW & Phone & $\begin{array}{l}\text { Vegetation reports; validation sets; } \\
\text { visit in August }\end{array}$ \\
\hline
\end{tabular}


Initinted By/

Afriliation

JE TUll/TSP

DE Walker/TSP

Julg 1993

WA Bishop/TSP

K Charlee/TSP Staff

G Combs/TSP Staff

G Combs/TSP Staff

SM Finch/BNW

P Houck/CDC

EB Llebow/BNW

EB Llebow/BNW

EB Llebow/BNW

EB Llebow/BNW

PG McGavran/TSP

AH Murphy/TSP

K Niles/TSP StafI
Contact/

Affllation

DB Shipler/BNW

Phone

EB Llebow/BNW

Phone

EB Llebow/BNW

Phone

GL Harvey/BNW

Phone

SM Finch/BNW

GL Harvey/BNW

Phone

B Shleien/TSP

EB Llebow/BNw

WA Bishop/TSP

D Emst/ST

DE Walker/TSP

Phone

JR Wilkinson/

CTUIR

SM Finch/BNW

JV Ramsdell/BNW

GL Harvey/BNW

Phone

Phone

Phone

Phone

Phone

Phone

Phone
Type

subject

B Shlelen letter on monltoring data; key air nuclides / majority ok; access records: $u / s$ workshop; releasing tr.formation

July NAWG meeting: schedule for work under $C D C$ contracts

Follow-up from TSP meeting

Arranging for document reviews

Record holder for Frultland Elementary School students who had whole body counts during 1963-1968

Resumes of members particlpating in milk distribution meeting; actions and assignments resulting from the recent TSP Communications Sub. committee meeting in Post Falls, ID

Support for the TSP Budget/Fiscal Subcommittee meeting

Invitation to take part in FY 1994 Training

YIN work status; presentation at NAWG meeting; comments on "Calendar of Events" memory prompt: Colville work status; presentation at NAWG meeting: presentation at Emergency Training Course

Preliminary alr pathway dose estimates

Follow-up from TSP meeting

Preliminary alr pathway dose estumates

Phone Whole body count/badge with correct security clearance level

Sensituvity/uncertainty analysis

Printout of graphic depicting the study area for fact sheet usage 


\begin{tabular}{|c|c|c|c|}
\hline $\begin{array}{l}\text { Initiated By/ } \\
\text { Aerrilintion }\end{array}$ & $\begin{array}{l}\text { Contact/ } \\
\text { Afrillation }\end{array}$ & Type & subject \\
\hline MA Robkın/TSP & GL Harvey/BNW & Phone & $\begin{array}{l}\text { Hard coples of various Hanford } \\
\text { documents for review: continue to } \\
\text { assist MA Robkin in requesting and } \\
\text { recetving documents of interest to } \\
\text { the HEDR Project }\end{array}$ \\
\hline DB Shipler/BNW & B Shleien/TSP & Phone & $\begin{array}{l}\text { Visit to BNW; fax copy of recent list } \\
\text { of documents to Reading Room }\end{array}$ \\
\hline DB Shipler/BNW & JE TUl/TSP & Phone & $\begin{array}{l}\text { Tribal doses; Nugyen allegation - alr } \\
\text { model-1G inquiry; status of codes } \\
\text { and source terms; document access }\end{array}$ \\
\hline B Shlelen/TSP & SM Flnch/BNW & Phone & $\begin{array}{l}\text { Date to review card catalog in August: } \\
\text { revised schedule for August visit }\end{array}$ \\
\hline \multicolumn{4}{|l|}{ Augunt 1993} \\
\hline B Aripa/CT & TA Ikenberry/BNW & Phone & $\begin{array}{l}\text { Inltial dose estimates to Colville } \\
\text { Natural Resources Council }\end{array}$ \\
\hline DS Barth/BNW & DB Shipler/BNW & Phone & $\begin{array}{l}\text { TSP meeting arrangements; update } \\
\text { review; compliments on staff } \\
\text { support for TSP meetIngs }\end{array}$ \\
\hline WA Blshop/TSP & EB Llebow/BNW & Phone & $\begin{array}{l}\text { Summary of ATSDR meeting; status } \\
\text { of CDC contracting process with } \\
\text { tribes: long-term work plans }\end{array}$ \\
\hline K CharLee/TSP Staff & SM Finch/BNW & Phone & Valldation schedule \\
\hline $\begin{array}{l}\text { PR Chevalier/BNW } \\
\text { and FP Brauer/BNW }\end{array}$ & BNW/Sequilm & Phone & Set up meeting with B Shleien/TSP \\
\hline PR Chevalier/BNW & CDC/Atlanta & Phone & $\begin{array}{l}\text { Badges for CW Miller, } C M \text { Wood, and } \\
R \text { Whitcomb of } C D C \text { for visit to BNW }\end{array}$ \\
\hline G Combs/TSP Stafl & GL Harvey/BNW & Phone & $\begin{array}{l}\text { Data for development of public } \\
\text { Information materials; access to site } \\
\text { photos for HHIN use; photos of two } \\
\text { TSP members for use in upcoming } \\
\text { TSP communlcations publications }\end{array}$ \\
\hline K CharLee/TSP Staff & GL Harvey/BNW & Phone & $\begin{array}{l}\text { Discussed TSP's tracking of specific } \\
\text { boxes and documents and efforts to } \\
\text { establish a comprehensive list of all } \\
\text { TSP revlewed materlals }\end{array}$ \\
\hline NJ Germond/TSP & GL Harvey/BNW & Phone & $\begin{array}{l}\text { Information on litigation review of } \\
\text { unclassified documents at the } \\
\text { Federal Bullding }\end{array}$ \\
\hline R Heusser/DOE-HQ & SM Finch/BNW & Phone & Document access process \\
\hline
\end{tabular}




\begin{tabular}{|c|c|c|c|}
\hline $\begin{array}{l}\text { Initlated By/ } \\
\text { Anillation }\end{array}$ & $\begin{array}{l}\text { Contact/ } \\
\text { Amillation }\end{array}$ & Type & Bubject \\
\hline TA lkenberry/BNW & B Aripa/CT & Phone & Food consumption data \\
\hline L Kaplan/HHIN & BA Napier/BNW & Phone & $\begin{array}{l}\text { Dominant radionuclides, Including } \\
\text { sources for Ar-41 to alr and } \mathrm{Cs}-137 \\
\text { to rtver: pathways of exposure for } \\
\text { varlous radionuclides }\end{array}$ \\
\hline EB Lebow/BNW & B Aripa /CT & Phone & $\begin{array}{l}\text { Agency for Toxic Substances and } \\
\text { Disease Registry meeting in } \\
\text { Richland. WA }\end{array}$ \\
\hline EB LJebow/BNW & WA Blshop/TSP & Phone & $\begin{array}{l}\text { Update on tribes' river pathways } \\
\text { Input and preliminary dose esti- } \\
\text { mates based on tribal data } \\
\text { summartes }\end{array}$ \\
\hline EB Llebow/BNW & H Rueben/NPT & Phone & $\begin{array}{l}\text { BNW needs instructions from Tribe } \\
\text { regarding disposition of data; clart- } \\
\text { flcation of age cohorts including in } \\
\text { food summartes; coples of letter } \\
\text { samples with altcrnative instruc. } \\
\text { Uons to BNW }\end{array}$ \\
\hline EB Llebow/BNW & DE Walker/TSP & Phone & $\begin{array}{l}\text { Update on tribes' tiver pathways } \\
\text { input and preliminary dose estl. } \\
\text { mates based on tribal data sum. } \\
\text { martes; tribal demographic } \\
\text { distribution data sources }\end{array}$ \\
\hline K Nules/TSP Staf & GL Harvey/BNW & Phone & $\begin{array}{l}\text { Maps and information regarding } \\
\text { ML Blazek's clearance update }\end{array}$ \\
\hline M Power/TSP Stafl & GL Harvey/BNW & Phone & $\begin{array}{l}\text { Meeting to evaluate BNW's assls. } \\
\text { tance with developing public } \\
\text { information materials that compll- } \\
\text { ment forthcoming technical } \\
\text { documents }\end{array}$ \\
\hline MA Robkin/TSP & GL Harvey/BNW & Phone & $\begin{array}{l}\text { Fact sheet development on other } \\
\text { Hanford releases }\end{array}$ \\
\hline GS Roessler/TSP & BA Napler/BNW & Fax & $\begin{array}{l}\text { Comments on TSP revlew of dose } \\
\text { parameters }\end{array}$ \\
\hline M Saporito/HTDS & BA Napler/BNW & Phone & $\begin{array}{l}\text { Procedure for assigning consump } \\
\text { ton rates of unknown brands of } \\
\text { milk from surveys: numertcal codes } \\
\text { for dalrtes and creameries }\end{array}$ \\
\hline DB Shipler/BNW & DS Barth/TSP & Phone & $\begin{array}{l}\text { DS Barth. GS Roessler, and } \\
\text { B Shlelen here } 8 / 19 \& 20 ; \text { brlefed } \\
\text { on HQ document accesslbillty }\end{array}$ \\
\hline
\end{tabular}




\begin{tabular}{|c|c|c|c|}
\hline $\begin{array}{l}\text { Inltlated By/ } \\
\text { Amillation }\end{array}$ & $\begin{array}{l}\text { Contact/ } \\
\text { Amallation } \\
\end{array}$ & Trpe & subject \\
\hline DB Shlpler/BNW & B Shlelen/TSP & Phone & $\begin{array}{l}\text { Set up meetung with JK Soldat to } \\
\text { talk about } 1-129\end{array}$ \\
\hline DB Shipler/BNW & JE TIII/TSP & Phone & $\begin{array}{l}\text { DS Barth to lead revtew of valida } \\
\text { toon: tentative meeting date for } \\
\text { release of dose reports; TSP/CDC to } \\
\text { gather feeding regime informatlon; } \\
\mathrm{H} Q \text { meeting on document access }\end{array}$ \\
\hline B Shlelen/TSP & GL Harvey/BNW & Phone & $\begin{array}{l}\text { Support for an upcoming visit to } \\
\text { review documents/materials }\end{array}$ \\
\hline B Shlelen/TSP & DB Shipler/BNW & Phone & $\begin{array}{l}\text { FP Brauer/BNW gathered lodine- } \\
129 \text { information and other entities } \\
\text { and will meet with B Shlelen }\end{array}$ \\
\hline B Shlelen/TSP & ME Thilede/BNW & Phone & Outline of Milestone $0502 \mathrm{C}$ report \\
\hline $\mathrm{J}$ Thomas/HEAL & BA Napler/BNW & Phone & $\begin{array}{l}\text { Badging for } 8 / 19 \text { TSP validation } \\
\text { review }\end{array}$ \\
\hline JE TUIITSP & DB Shipler/BNW & Phone & TSP review of validation results \\
\hline M Turley/Pasco & GL Harvey/BNW & Phone & $\begin{array}{l}\text { Provided HEDR and HTDS informa- } \\
\text { ton and contact numbers for } \\
\text { questions and malling lists }\end{array}$ \\
\hline
\end{tabular}




\section{Distribution}

No. of

Coples

\section{OEDSTE}

Technical Steertine Panel

D. S. Barth

Untversity of Nevada 4505 Maryland Parkway

Las Vegas, NV 89154

W. A. Bishop 2503 Wedgewood Court S.E. Olympla, WA 98501

M. L. Blazek Oregon Department of Energy 625 Marton Street N.E. Salem, OR 97310

O. O. Caldwell

Tulsa Clty-County Health Dept. 4616 East 1 Bth Street

Tulsa, OK 74112

S. N. Davis

Dept. of Hydrology \& Water Resources

Bullding 11

Untversity of Arizona

Tucson, AZ 85721

N. J. Germond

224 Iron Mountain Blvd.

Lake Oswego, OR 97034

P. C. Kllingeman

Ctvil Engineering Dept.

Apperson Hall 202

Oregon State Untversity

Corvallis, OR 97331-2302

K. J. Kopecky

Fred Hutchinson Cancer

Research Center

1124 Columbla Street

Seattle. WA 98104

P. D. McGavran

Dept. of Health and Welfare $480 \mathrm{~W}$. State Street, 4th Floor

Bolse, ID 83720-5450
No. of

Coples

R. L. Morrtll

Dept. of Qeography, DP-10

University of Washington

Seattle, WA 98196

A. H. Murphy

3115 NW McKunley Drive

Corvallis, OR 97330

D. W. Price

Agricultural Economics

Hulbert Hall Room 211

Washington State Untveraity

Pullman, WA 99164-6210

M. A. Robkin

Radiological Sciences, SB-75

Untveralty of Washington

Seattle, WA 98185

O. S. Roessler

Route 1, Box 139H

Elyuian, MN 56028

B. Shlelen

2421 Homeatead Drive

Suver Springs, MD 20902

A. P. Slickpoo, Sr.

809 Nez Perce Lane

P. O. Box 311

Kamlah, ID 83536

J. E. TWII

Route 2 Box 122

Neeses. SC 29107

D. E. Walker, Jr.

P.O. Box 4147

Boulder, CO 80306

Other

2 DOE Omce of Sclentunc and

Technical Information

Technical Information Center

P.O. Box 62

Oak RIdge, TN 37830 
M. A. Andrews

Canadlan Embassy

501 Pennsylvanla Avenue N.W.

Washington, DC 20001

B. Aripa

Colville Confederated Tribes

P.O. Box 150

Nespelem, WA 99155

D. M. Bemick

KIrkland and Ellis

200 East Randolph Drive

Chicago, IL 60601

\section{Bonga}

Kallopel Tribe

P.O. Box 39

Uak, WA 99180

B. O. Brooks, EH-421

Department of Enerky

Room J.112

Gernantown. MD 20545

H. Burgess

Oeneral Electric Nuclear Energy

175 Curtner Avenue

Mall Code 822

San Jose, CA 95125

18

K. Charlee

Technical Support and Public

Information

P.O. Box 47651

Olympla, WA $98504-7651$

L. E. Denham

Centers for Disease Control and Prevention 4770 Buford Highway, N.E.

M.S. F35

Atlanta, OA $30341-3724$

M. R. Donnelly

Public Health Service

Centers for Disease Control and Prevention

2201 6th Avenue, M.S. RX-22

Seattle. WA 98121

J. Erickson

Washington State Dept. of Health

M.S. LE.13

Olympla, WA 98504-0095
D. Ernol

Spokane Tribe

P.O. Box 100

Wellpinlt, WA 99040

A. Fingerel, OC-22

Department of Energy

Forrestal Bldg. Room 6H.087

1000 Independence Avenue S.W.

Washington, DC 20585

K. Oubble, Secretary

Washington Slate Dept. of Health

M.S. ET.21

Olympla, WA 98504

R. S. Haber

1840 Willamelte Street

Eugene, OR 97401

H. A. Haerer

Golder Assoclates, Inc.

4104 148th N.E.

Redmond, WA 98052

A. P. Hull

Safety \& Environmental

Protection Division

Bullding 535A

Brookhaven Natlonal Laboratory

Upton. NY 11973

D. B. Manders

Chronic Disease Epldemiology

Washington State Dept. of Health

M.S. EY-12

1408 State Street

Olympla, WA 98504

R. Mathlas, S-1

Department of Energy

Forrestal Bldg. Room 7A-257

1000 Independence Avenue S.W.

Washington, DC 20585

N. Morin

Rocky Flats Program UnIt

Environmental Epidemlology Division

Colorado State Dept. of Health

4210 E. 11 th Avenue

Denver, CO 80220 
D. V. Nelson, ER-8.2

Department of Energy

Once of Asseasment and Support

Washington, DC 20885

D. Oliver

Washington state Dept, of Social \& Health Services

Taxdc Subatances Section, M.S. LD.11

Olympla. WA 98504

\section{Queahpama}

Confederated Tribes of the

Warm Springe Reservation

P.O. Bax C

Warm Springs, OR 97761

J. H. Rueben

Nez Perce Tribe

P.O. Box 308

Lapwal, ID 83540

D. Saluakin

Confederated Tribes and Bands of the Yakuma Indian Nation

P.O. Box 181

Toppenish, WA 98948

S. H. Sell

Tennessee State Dept. of Health \& Environment

C. $1-130$ Cordell Hull Bullding

Nashville, TN 37247.4912

D. Seyler

Coeur d'Alene Tribe

Plummer, ID 83851

2 S. Shaver

Agency for Toxdc Subotances \& Disease

Registry

1600 Clinton Road, M.S. E56

Atlanta, OA 30333

C. L. Sherwood, AC-21

Department of Energy

Room D.408

Germantown, MD 20545

K. F. Sparks

Shea \& Gardner

1800 Massachusetts Avenue N.W.

Washington, D.C. 20036 o. Thomas

Agency for Toxjc Substances \& Disease Regiatry

1200 oth Avenue, M.S. HW. 113

Seattle, WA 98101

J. P. Thomas

HEAL.

$1720 \mathrm{~N}$. Ah

Spokane. WA 99205

DNR Hanford Projecte

Confederated Tribes of the

Umatilla Indian Reservation

P.O. Box 638

Pendleton, OR 97801

S. Vendetter

Benton-Frankdin Diatrict Health Dept.

$800 \mathrm{~W}$. Canal Drtve

Kennewick. WA 99336

B. Weakley, IE.12

Department of Eneray

Forreatal Bldg. Room 1E.218

1000 Independence Avenue S.W.

Washington. DC 20585

R. White

History Department, M.S. DP.20

University of Washington

Sealtle, WA 98195

\section{ONSITE}

1 Hanfond Envimonmental Health Eoundation

S. E. Dietert

B5.16

1 Westlnohouse Hanford Company

O. D. Carpenter

B2.16

- DOF, Richland Operallone OMare

T. A. Bauman, COM

A7.7B

R. F. Brich. TSD

A5.65

R. M. RossellI, AMT

A7.70

R. R. Tubbatts, PBD

A7.89

Public Reading Room (5) 
No. of

Conte:

46 Battelle. Padife NortherentLaboratorten

D. M. Anderson

$\mathrm{Ka} \cdot 1 \mathrm{~s}$

A. C. Bampton

O. L. Black (5)

A. J. Brother

K. W. Burk

S. D. Cannon

P. R. Chevaller

D. K. Cypher

D. H. Denham

D. E. Deonlg|

P. W. Eollnger

W. T. Farris

S. M. Pnch

M. D. Freshley

R. O. Oubert

W. A. Olawe (3)

R. H. Oray

S. P. Oydesen

K3.64

K6.77

K7.34

K3.63

K1.33

P8.65
No. of

Conien

C. L. Harvey

C. M. Heeb

T. A. Ikenberry

E. B. Luebow

D. L. Martin

A. H. McMalan

B. A. Napler

J. V. Ramedell

C. L. Savard

D. B. Shipler

S. V. Shoemaker

S. A stage

C. D. Taylor

W. L. Templeton

M. E. Thiede

W. H. Waller

Publlahing Coordination

Records Center (2)

Technleal Library (2)
PNWD.1080.12 HEDR

UC. 000
K1.77

Ko-34

K3. 14

HARC

K3.70

K6.62

K3. B4

Ko. 68

Ko.88

$\mathrm{KI} .28$

$\mathrm{K} 7.28$

K6. 85

B). 40

KI. 30

Ka.62

Ko.60

$\mathrm{KI.03}$

K3.70

Po.66 

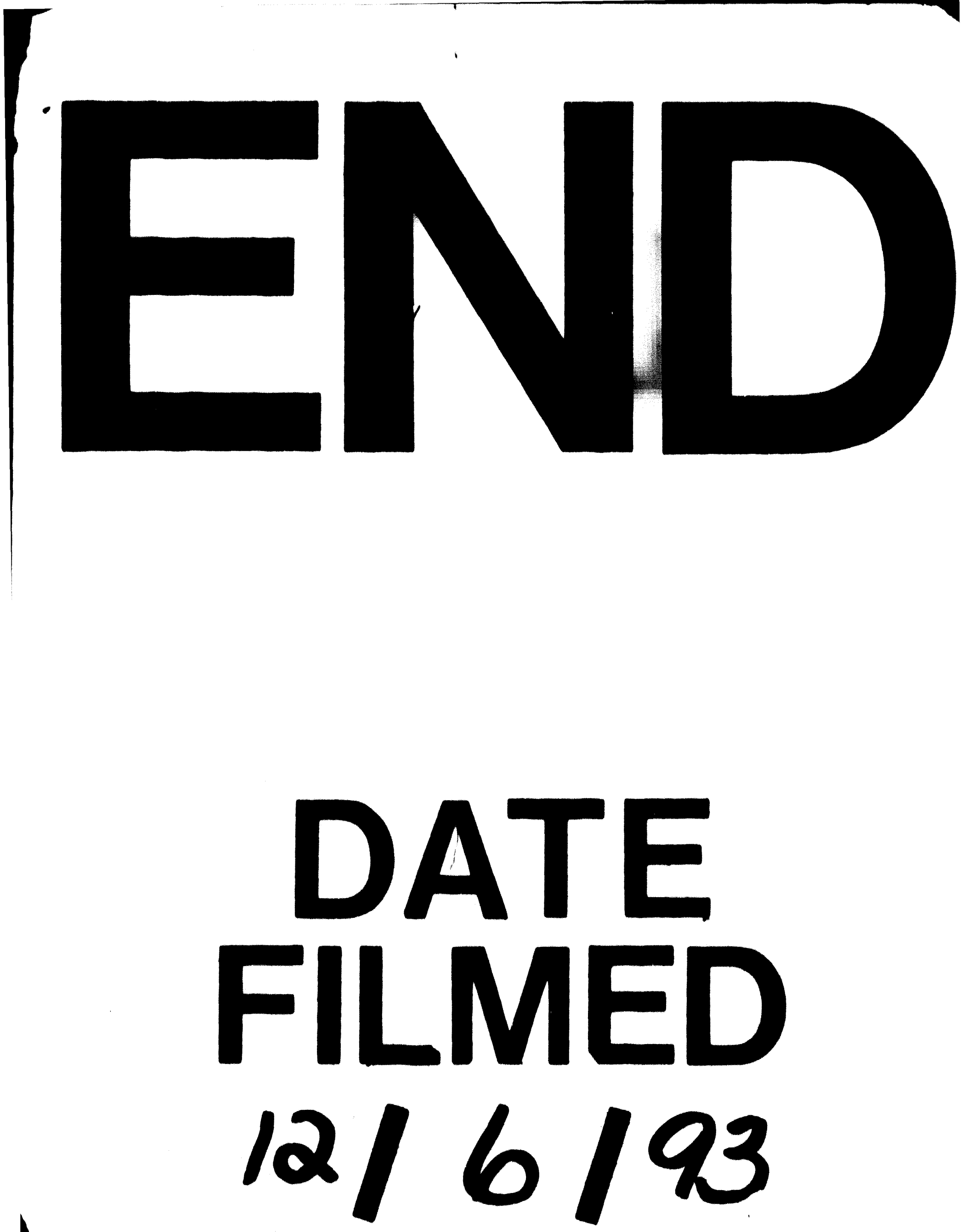


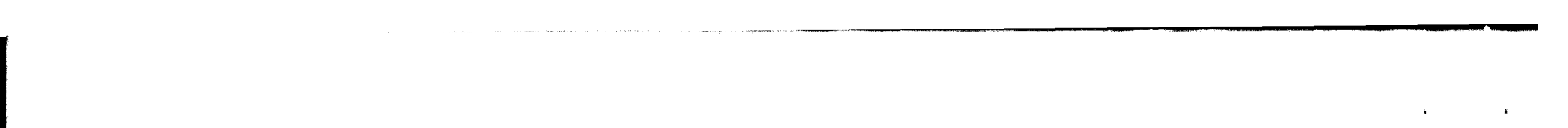

-

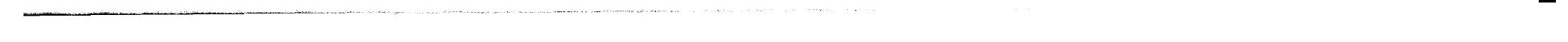

